Article

\title{
Synthesis, Characterization, and Reaction Studies of Pd(II) Tripeptide Complexes
}

\author{
Lindsey J. Monger ${ }^{1}\left(\mathbb{D}\right.$, Dmitrii Razinkov ${ }^{1}\left(\mathbb{D}\right.$, Ragnar Bjornsson $^{2}$ and Sigridur G. Suman ${ }^{1, *(\mathbb{C}}$ \\ 1 Science Institute, University of Iceland, Dunhagi 3, 107 Reykjavik, Iceland; ljm4@hi.is (L.J.M.); \\ dmr2@hi.is (D.R.) \\ 2 Max Planck Institute Chemical Energy Conversion, 45470 Mülheim an der Ruhr, Germany; \\ ragnar.bjornsson@cec.mpg.de \\ * Correspondence: sgsuman@hi.is
}

Citation: Monger, L.J.; Razinkov, D.; Bjornsson, R.; Suman, S.G. Synthesis, Characterization, and Reaction Studies of Pd(II) Tripeptide Complexes. Molecules 2021, 26, 5169. https://doi.org/10.3390/

molecules26175169

Academic Editor: Farkas Etelka

Received: 27 July 2021

Accepted: 23 August 2021

Published: 26 August 2021

Publisher's Note: MDPI stays neutral with regard to jurisdictional claims in published maps and institutional affiliations.

Copyright: (c) 2021 by the authors. Licensee MDPI, Basel, Switzerland. This article is an open access article distributed under the terms and conditions of the Creative Commons Attribution (CC BY) license (https:// creativecommons.org/licenses/by/ $4.0 /)$.

\begin{abstract}
The aqueous synthesis of $\mathrm{Pd}(\mathrm{II})$ complexes with alkylated tripeptides led to the hydrolysis of the peptides at low $\mathrm{pH}$ values and mixtures of complexed peptides were formed. A non-aqueous synthetic route allowed the formation and isolation of single products and their characterization. $\mathrm{Pd}(\mathrm{II})$ complexes with $\alpha$-Asp(OR)AlaGly(OR), $\beta$-Asp(OR)AlaGly(OR), and TrpAlaGly(OR) $(\mathrm{R}=\mathrm{H}$ or alkyl) as tri and tetradentate chelates were characterized. The tridentate coordination mode was accompanied by a fourth monodentate ligand that was shown to participate in both ligand exchange reactions and a direct removal to form the tetradentate coordination mode. The tetradentate coordination revealed a rare a hemi labile carbonyl goup coordination mode to Pd(II). Reactivity with small molecules such as ethylene, acids, formate, and episulfide was investigated. Under acidic conditions and in the presence of ethylene; acetaldehyde was formed. The Pd(II) is a soft Lewis acid and thiophilic and the complexes abstract sulfur from episulfide at apparent modest catalytic rates. The complexes adopt a square planar geometry according to a spectroscopic analysis and DFT calculations that were employed to evaluate the most energetically favorable coordination geometry and compared with the observed infrared and NMR data.
\end{abstract}

Keywords: Pd(II); tripeptide; AspAlaGly; $\beta$-AspAlaGly; TrpAlaGly; DFT

\section{Introduction}

Although the interactions of metal ions with various biological molecules, including peptides, have been well studied, the focus of these examinations is primarily under the purview of metallodrugs and metal toxicity [1-5]. However, modified biocompatible or biologically relevant frameworks are also applied to the mimic natural catalyst's design [6].

Peptides coordinate to metal ions via the amide backbone, but to initiate coordination, a primary ligating group must be present [7-10]. For small peptides, this is facilitated by the presence of a side chain with a strong donor group or by the primary amine which tends to form five- or six-membered ring chelates through the amino, amide backbone or the carboxylate moiety [7]. Preferences for coordination vary between metal ions where $\mathrm{Pd}(\mathrm{II})$ has a high affinity for nitrogen and sulfur as soft donor atoms [11-16] and can initiate the deprotonation of amides, forming chelate at $\mathrm{pH}$ values below a $\mathrm{pH}$ of $2[17,18]$.

Strong ligating side chain moieties also serve as anchor groups; histidine is a wellstudied example [19-21]. The so-called ATCUN-motif (Amino Terminal $\mathrm{Cu}$ and $\mathrm{Ni}$ ) forms strong coordinating ligands with histidine as the third amino residue for the $\mathrm{N}$-terminus (as seen in Figure 1a). Innumerable possibilities of side chain combinations and modifications allow a variety of metal complexes to be synthesized with tunable geometries and electronic properties $[8,10,20,22-29]$. 

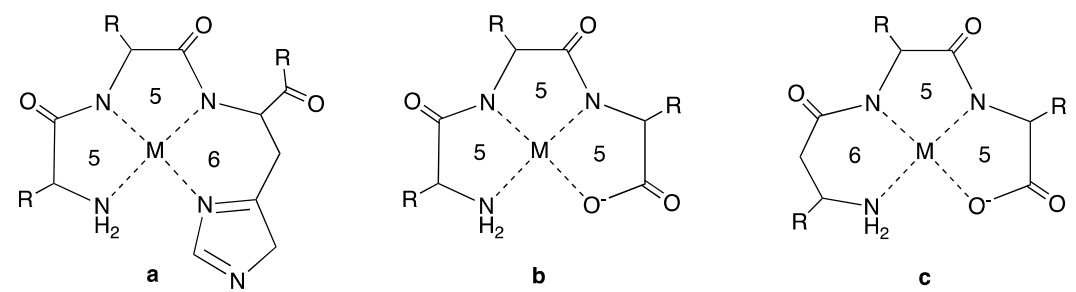

Figure 1. (a) ATCUN-motif, when $\mathrm{M}=\mathrm{Ni}, \mathrm{Cu}$. (b) Coordination motifs for metal peptide complexes, $\mathrm{M}=\mathrm{Pd}, \mathrm{Ni}$, or $\mathrm{Cu}$. (c) Coordination motifs for metal peptide complexes with $\kappa^{4}[6,5,5]$ chelation.

Bioinspired applications make use of modified biocompatible or biologically relevant frameworks to imitate the natural catalyst design [6]. Weakly coordinating chelates may be incorporated into the design of metal complexes to function as an "on-off" switch during catalysis. The modification of the carboxylic acid to form an ester could act in such a manner. A challenge encountered with this strategy is the ability of $\mathrm{Pd}(\mathrm{II})$ to catalyze ester hydrolysis [30]. In order to avoid this undesirable reaction, non-aqueous conditions were employed. In previous work we described the synthesis of three new tripeptide ligands and investigated the effects of $\mathrm{pH}$ on their coordination to $\left[\mathrm{Pd}(\mathrm{en})\left(\mathrm{H}_{2} \mathrm{O}\right)\right]^{2+}[31]$. The ligands were designed to form either $\mathrm{K}^{4}[5,5,5]$ (Figure $1 \mathrm{~b}$ ) or $\mathrm{K}^{4}[6,5,5]$ (Figure 1c) membered ring tetradentate ligands, allowing for an adjustable ligand design for ligands 1 and $\mathbf{2}$ (Figure 2). A similar approach employed histidine on the C-terminus of di- and tri- peptides with $\kappa^{4}[5,5,6]$ (Figure 1c)-type coordination [20,25]. Tryptophan was chosen for ligand three to impart organosolubility to an expected $\kappa^{4}[5,5,5]$ coordination. In addition to the primary amine and carboxylate $\mathrm{C}$-terminal functional groups, indole complexation was reported through the secondary amine [32], the indole C2, [33,34], and the C3 carbon [35]. The tripeptides exhibited their maximum expected chelating ring sizes at the $\mathrm{N}$-terminus and aqueous in situ studies confirmed it is possible to form complexes with $\kappa^{4}[n, 5,5](n=8,6$, 5) chelates [31]. The molecular ions of the complexes were found and matched with their simulated isotope patterns in the ESI MS of the complexes. However, ester hydrolysis led to multiple species present in the reaction mixtures and non-isolable products.

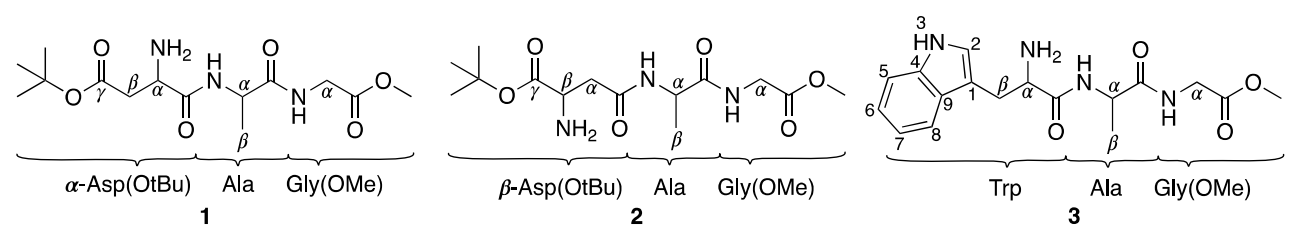

Figure 2. Tripeptide ligands 1-3.

This work outlines the synthesis of Pd(II) complexes of ligands 1-3, and their characterization. The tetradentate complexes were subjected to reactivity studies to investigate their general properties.

\section{Results}

The ligand $\alpha$-Asp $(\mathrm{OtBu}) \mathrm{AlaGly}(\mathrm{OMe})(\mathbf{1})$ (Figure 2) was used to develop a synthetic strategy focused on achieving a neutral tetradentate $\mathrm{Pd}(\mathrm{II})$ complex. A summary of the synthetic routes employed is shown in Scheme 1. The procedure established was applied to ligands $\mathbf{2}$ and $\mathbf{3}$ (Figure 2). 


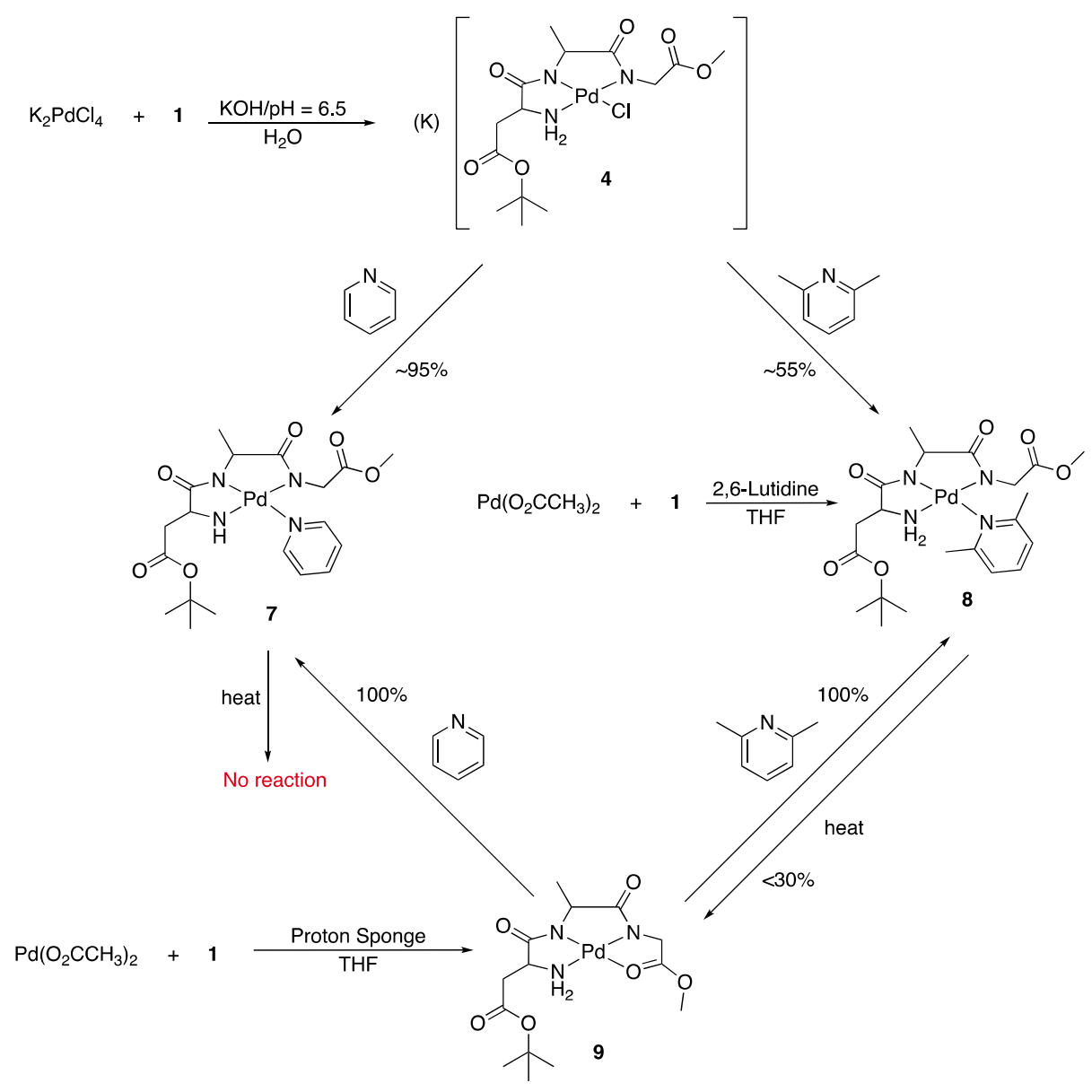

Scheme 1. Scheme depicting synthetic routes and hemi-lability of complexes.

\subsection{Synthesis and Cation Exchange of Mono-Anionic Complexes 4-6}

The coordination of tripeptide-1 with $\mathrm{Pd}(\mathrm{II})$ and degree of hydrolysis are highly dependent on $\mathrm{pH}$, rendering standard synthetic techniques ineffective [31]. Methods to establish an aqueous synthetic strategy to form neutral tetradentate $\mathrm{Pd}(\mathrm{II})$ complexes were explored [36]. In this strategy, $\mathrm{K}_{2} \mathrm{PdCl}_{4}$ was dissolved in water and added to an aqueous solution of $\mathbf{1}$, then the $\mathrm{pH}$ was adjusted to $\sim 6.5$. The major product was the charged species $\mathrm{K}\left[\mathrm{Pd}\left\{\alpha-\mathrm{Asp}\left(\mathrm{O}^{t} \mathrm{Bu}\right) \mathrm{AlaGly}(\mathrm{OMe})\right\} \mathrm{Cl}\right], 4$. The composition of 4 was confirmed by mass spectrometry along with the presence of the $\mathrm{Pd}_{2} \mathrm{~L}_{2} \mathrm{Cl}$ dimer. The coordination of 4 was $\kappa^{3}\left[\mathrm{NH}_{2}, \mathrm{~N}, \mathrm{~N}\right]$ as determined by spectroscopic data.

Complex 4 was synthesized with an improved reaction control by transitioning into a non-aqueous environment. Using $\mathrm{Pd}\left(\mathrm{CH}_{3} \mathrm{CN}\right)_{2} \mathrm{Cl}_{2}$ as the starting complex and substituting $\mathrm{KOH}$ for two molar equivalents of triethylamine, resulted in the isolation of the complex $\left(\mathrm{Et}_{3} \mathrm{NH}\right)\left[\mathrm{Pd}\left\{\alpha-\mathrm{Asp}\left(\mathrm{O}^{t} \mathrm{Bu}\right) \mathrm{AlaGly}(\mathrm{OMe})\right\} \mathrm{Cl}\right], 5 . \mathrm{Pd}\left(\mathrm{CH}_{3} \mathrm{CN}\right)_{2} \mathrm{Cl}_{2}$ was isolated as the transisomer [37]. The acetonitrile had a stronger trans influence compared to $\mathrm{Cl}^{-}$[38] and the presence of the chloro ligand in four may be owed to its slower displacement. The ${ }^{1} \mathrm{H}-\mathrm{NMR}$ resonances for different cationic salts $\mathbf{4}$ and $\mathbf{5}$ were identical, whereas the latter had an organic cation. Excess $\mathrm{Et}_{3} \mathrm{NH}^{+}$proved difficult to remove, but this was resolved by performing a cation exchange reaction with $\mathrm{PPh}_{4}{ }^{+}$to produce complex six, $\left(\mathrm{Ph}_{4} \mathrm{P}\right)[\mathrm{Pd}\{\alpha-$ Asp $\left.\left.\left(\mathrm{O}^{t} \mathrm{Bu}\right) \mathrm{AlaGly}(\mathrm{OMe})\right\} \mathrm{Cl}\right]$. The cation exchange did not noticeably affect the complex ${ }^{1} \mathrm{H}-\mathrm{NMR}$ resonances. However, this led to the loss of yield and some decomposition. After the cation exchange, the integration of the ${ }^{1} \mathrm{H}-\mathrm{NMR}$ resonances for $\mathrm{Ph}_{4} \mathrm{P}^{+}$and complex 6 confirmed 4-6 were mono-anionic, but had the same coordination geometry seen in Scheme 1 labeled 4. 


\section{Ligand Exchange Reactions}

To form the neutral complex (Scheme 1), reactions to exchange or remove the chloride were performed. Pyridine (Py) was added to the potassium salt (4) and the results monitored with NMR (Scheme 1,7). The spectrum showed new peaks in the 7-8 ppm region indicating coordination of pyridine. Integration confirmed the chloride was successfully replaced by pyridine. When seven was heated at $110{ }^{\circ} \mathrm{C}$ overnight, pyridine remained coordinated. In a second reaction, 2,6-lutidine ( $\mathrm{Lu}$ ) was added to 4 and the reaction monitored by ${ }^{1} \mathrm{H}-\mathrm{NMR}$. Upon lutidine addition, the integration of its peaks in the NMR showed the incorporation of about $0.5-0.6 \mathrm{~mol}$ eq. of lutidine for the incomplete replacement of the chloride (Scheme 1, 8).

A neutral palladium complex with coordinated lutidine was synthesized directly using $\mathrm{Pd}(\mathrm{OAc})_{2}$ and a two equivalence of 2,6-lutidine in dry THF (Scheme 1, 8). Upon heating 8 overnight at $110{ }^{\circ} \mathrm{C}$, tracking this reaction via ${ }^{1} \mathrm{H}-\mathrm{NMR}$, a minor species started to form. Integration suggested the new species was less than $30 \%$ mol of the total yield where the changes to the resonances in the ${ }^{1} \mathrm{H}-\mathrm{NMR}$ of 8 upon heating were clearly observed. The formation of free Lu was also observed, confirming that lutidine's labile coordination may be controlled with heat. This reaction was able to form the desired tetradentate complex $\operatorname{Pd}\left\{\alpha-\mathrm{Asp}\left(\mathrm{O}^{t} \mathrm{Bu}\right) \mathrm{AlaGly}(\mathrm{OMe})\right\}(9)$.

\subsection{Synthesis of Neutral Complexes Tetradentate Pd(II) Complexes 9-11}

A non-aqueous strategy for the formation of $\mathbf{9}$ was developed, wherein $\mathbf{1}$ and a Proton Sponge (1,8-Bis(dimethylamino)naphthalene) were dissolved in dry THF, followed by the addition of $\mathrm{Pd}(\mathrm{OAc})_{2}$ to the solution, and stirring under argon. The Proton Sponge is a non-nucleophilic base which allows the last coordination site on the $\mathrm{Pd}(\mathrm{II})$ to remain open for the C-terminal ester to bind. The coordination of this complex is $\mathrm{K}^{4}\left[\mathrm{NH}_{2}, \mathrm{~N}, \mathrm{~N},=\mathrm{O}\right]$ with coordinated C-terminus methyl ester carbonyl as shown in Scheme 1. The composition of 9 was confirmed by mass spectrometry as well as an elemental analysis and fully characterized spectroscopically. This method established a synthetic approach of the neutral palladium tripeptide complex that was applied to ligands $\mathbf{2}$ and $\mathbf{3}$ to form $\mathbf{1 0}$ and 11. (Figure 3). Complexes $\mathbf{1 0}$ and $\mathbf{1 1}$ were synthesized in good to high yields and fully characterized. These complexes were soluble in DMSO and DMF and were slightly soluble in acetonitrile and alcohols. However, they were insoluble in most other organic solvents.

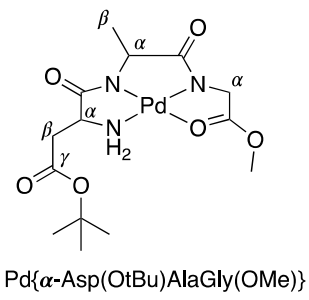

9

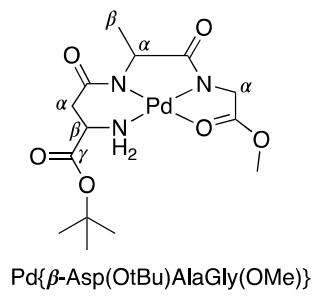

10

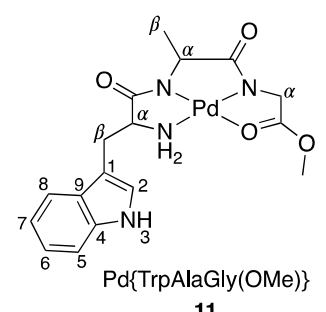

11

Figure 3. Tetradentate tripeptide Pd(II) complexes with coordinated ester carbonyl.

The tripeptide- 2 is an iso-peptide, meaning that it forms the peptide bond through the side chain carboxylic acid. When coordinated to a metal center via the $\mathrm{N}$-terminal amine and the nearest amide, the peptide forms a 6-membered chelate. In an aqueous medium at neutral $\mathrm{pH}$ this system presented a competing coordination to the side chain carbonyl forming the bidentate 5-membered $\kappa^{2}\left[\mathrm{NH}_{2}, \mathrm{O}\right]$ chelate instead of the $\kappa^{3}\left[\mathrm{NH}_{2}, \mathrm{~N}, \mathrm{~N}\right]$ amide backbone [31]. The $\mathrm{k}^{4}\left[\mathrm{NH}_{2}, \mathrm{~N}, \mathrm{~N}, \mathrm{O}\right]$ chelated complex could be formed in basic aqueous conditions at a $\mathrm{pH}$ value of $\sim 9$. However, $\mathrm{Pd}(\mathrm{II})$ catalyzed hydrolysis at this $\mathrm{pH}$ value led to $t$-butyl and methyl ester hydrolysis of up to $35 \%$ and $65 \%$. Thus, aqueous synthesis using two was not a viable option. However, utilizing the Proton Sponge as a base in dry THF yielded the $\kappa^{4}\left[\mathrm{NH}_{2}, \mathrm{~N}, \mathrm{~N},=\mathrm{O}\right]$ species, $\mathrm{Pd}\left\{\beta-\mathrm{Asp}\left(\mathrm{O}^{t} \mathrm{Bu}\right) \mathrm{AlaGly}(\mathrm{OMe})\right\}(\mathbf{1 0})$, in good yields.

Aqueous coordination studies of 3 with $\mathrm{Pd}(\mathrm{en})\left(\mathrm{H}_{2} \mathrm{O}\right)^{2+}$ revealed that the tryptophan indole participated in coordination [31]. The ${ }^{1} \mathrm{H}-\mathrm{NMR}$ study revealed that at a low $\mathrm{pH}$ 
the $\mathrm{NH}_{2}$ coordinated as expected and chelation continued to the Ala amide. However, as the $\mathrm{pH}$ was increased to $\sim 8$ the $\mathrm{K}^{4}\left[\mathrm{NH}_{\text {indole }}, \mathrm{N}, \mathrm{N}, \mathrm{O}\right]$ isomer was detected, forming an eight-membered ring. The study also showed that the methyl ester was hydrolyzed up to $75 \%$ under these conditions. Aqueous synthesis was, therefore, not attempted and $\mathbf{3}$ was complexed to $\mathrm{Pd}(\mathrm{OAc})_{2}$ in THF with the Proton Sponge. This yielded the $\kappa^{4}\left[\mathrm{NH}_{2}, \mathrm{~N}, \mathrm{~N},=\mathrm{O}\right]$ complex coordination mode (Figure $3, \mathbf{1 1}$ ).

\section{Ligand Exchange Reactions}

The coordinated ester carbonyl was expected to form a weak interaction with the metal center and act in a hemi-labile fashion. To test this, 9 was reacted with $1.5 \mathrm{~mol}$ eq of either $\mathrm{Lu}$ and Py and base coordination was monitored employing ${ }^{1} \mathrm{H}-\mathrm{NMR}$. Both ligand exchange reactions went to completion immediately; see Scheme 1. The comparison of ligand exchange reactions of $\mathrm{Lu}$ and Py with 4 (Cl ligand) and 9 (carbonyl ester) proved the dissociation of the carbonyl ester oxygen was more rapid and gave higher yields.

\subsection{DFT Calculations}

DFT calculations with a continuum solvation model were employed to determine the lowest energy structures in solution for complexes 4-11 which can be seen in Figure 4. (For cartesian coordinates, see Supplementary Materials). Several different binding modes and conformational possibilities were explored computationally. Due to the conformational flexibility of the tripeptide ligand, several conformers for each complex were available (primarily due different orientations of the Asp or Trp sidechains). The lowest energy conformer for each complex is shown in Figure 4 which was also used in the calculations of spectroscopic properties (Section 2.4). As the $\mathrm{Pd}(\mathrm{II})$ peptide complexes were preferably square planar, $\left[\mathrm{NH}_{2}, \mathrm{~N}, \mathrm{~N}\right]$ coordination was expected, and DFT results revealed this.
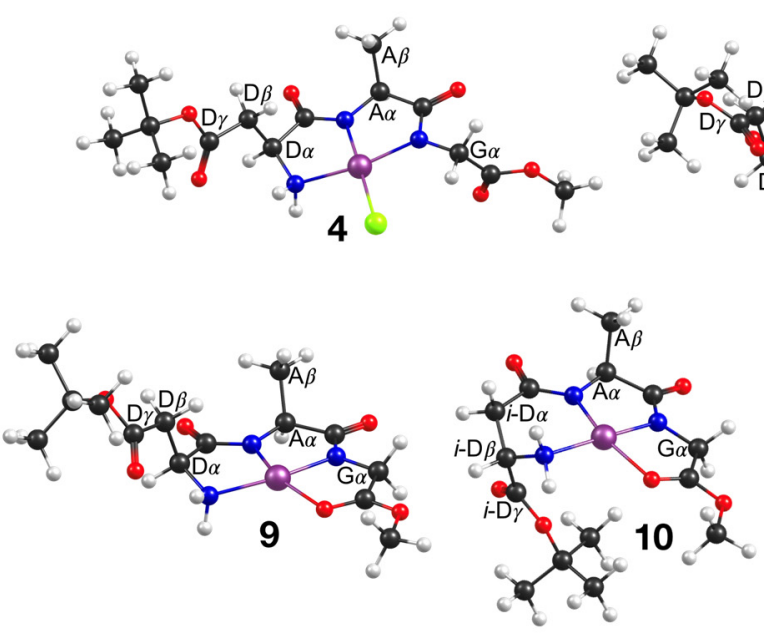
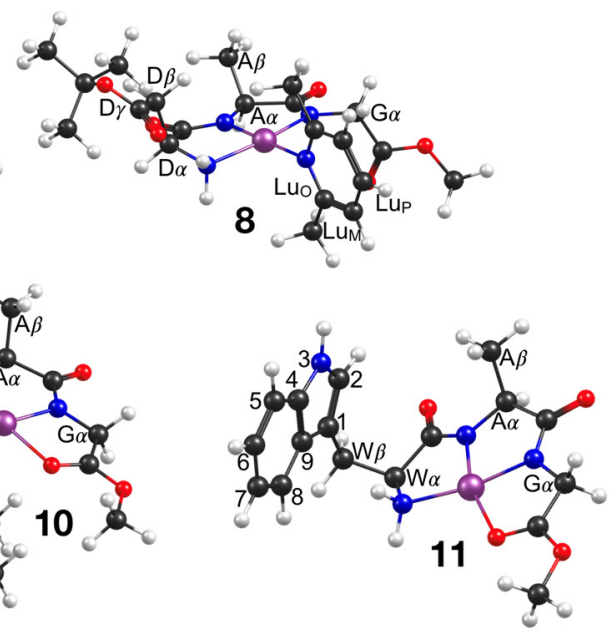

Figure 4. DFT-optimized structures of Pd(II) complexes 4, 8-11.

In comparing the bond angles of the complexes, distinctive patterns were observed. Table 1 lists the calculated bond angles and bond lengths for the complexes. The tridentate complexes 4 and 8 more closely adhered to the ideal square planar geometry of $90^{\circ}$. In contrast, the tetradentate complexes $\mathbf{9}$ and $\mathbf{1 1}$ had a much smaller $\mathrm{N}_{\text {gly }}-\mathrm{Pd}-\mathrm{O}_{\text {gly }}$ bite angle $\left(\sim 80^{\circ}\right)$, increasing the $\mathrm{NH}_{2}-\mathrm{Pd}-\mathrm{O}_{\text {gly }}$ coordination angle up to $\sim 113$ for 9 and 11. Whereas the six-membered ring of $\mathbf{1 0}$ increased the $\mathrm{NH}_{2}-\mathrm{Pd}-\mathrm{N}_{\text {ala }}$ bite angle from $\sim 83^{\circ}$ to $95^{\circ}$, and decreases the $\mathrm{N}_{\text {gly }}-\mathrm{Pd}-\mathrm{O}_{\text {gly }}$ to $100^{\circ}$. The bond length assigned to complexes $\mathbf{9}$ and $\mathbf{1 1}$ were similar, whereas the six-membered chelate of $\mathbf{1 0}$ affected all metal coordination bond lengths. 
Table 1. Calculated bond angles $\left(^{\circ}\right)$ and lengths $(\AA)$ for complexes 4, 8-11. $\mathrm{X}=\mathrm{Cl}(\mathbf{4})$, $\mathrm{Lu}(\mathbf{8})$, or $-\mathrm{OMe}$ $(9,10,11)$.

\begin{tabular}{cccccc}
\hline Bond Angle & $\mathbf{4}$ & $\mathbf{8}$ & $\mathbf{9}$ & $\mathbf{1 0}$ & $\mathbf{1 1}$ \\
\hline $\mathrm{NH}_{2}-\mathrm{Pd}-\mathrm{N}_{\text {ala }}$ & 82.84 & 82.71 & 82.97 & 95.01 & 82.61 \\
$\mathrm{~N}_{\text {ala }}-\mathrm{Pd}-\mathrm{N}_{\text {gly }}$ & 81.92 & 82.11 & 83.58 & 83.17 & 83.68 \\
$\mathrm{~N}_{\text {gly }}-\mathrm{Pd}-\mathrm{X}$ & 99.54 & 98.35 & 80.47 & 80.99 & 80.32 \\
X-Pd-NH & 95.70 & 96.88 & 112.90 & 100.54 & 113.38 \\
\hline Bond Length & & & & & \\
\hline $\mathrm{NH}_{2}-\mathrm{Pd}$ & 2.061 & 2.060 & 2.077 & 2.064 & 2.073 \\
$\mathrm{~N}_{\text {ala }}-\mathrm{Pd}$ & 1.940 & 1.942 & 1.916 & 1.964 & 1.911 \\
$\mathrm{~N}_{\text {gly }}-\mathrm{Pd}$ & 1.996 & 1.996 & 1.937 & 1.936 & 1.938 \\
$\mathrm{X}-\mathrm{Pd}$ & 2.355 & 2.070 & 2.142 & 2.109 & 2.142 \\
\hline
\end{tabular}

\subsection{Characterization}

Selected ${ }^{1} \mathrm{H}$ NMR and ${ }^{13} \mathrm{C}$ NMR spectroscopic data are given in Tables 2 and 3 respectively. Comparison of observed and calculated ${ }^{13} \mathrm{C}$ NMR data is given in Table 4 . Selected IR data is given in Table 5, and comparison of selected observed and calculated IR data is presented in Table 6.

Table 2. Summary of ${ }^{1} \mathrm{H} N M R$ data: $4=\mathrm{K}[\mathrm{Pd}(\mathbf{1}) \mathrm{Cl}], \mathbf{7}=\operatorname{Pd}(\mathbf{1}) \mathrm{Py}, \mathbf{8}=\operatorname{Pd}(\mathbf{1}) \mathrm{Lu}, \mathbf{9}=\operatorname{Pd}(\mathbf{1}), \mathbf{1 0}=\operatorname{Pd}(\mathbf{2})$, $11=\operatorname{Pd}(3)$.

\begin{tabular}{cccccccc}
\hline Chemical Shift $(\mathbf{p p m})$ & $\mathbf{4}$ & $\mathbf{7}$ & $\mathbf{8}$ & $\mathbf{8 + \boldsymbol { * }}$ & $\mathbf{9}$ & $\mathbf{1 0}$ & $\mathbf{1 1}$ \\
\hline $\mathrm{Py}_{\text {Ortho }}$ & - & 8.73 & - & - & - & - & - \\
$\mathrm{Py} / \mathrm{Lu}_{\text {Meta }}$ & - & 7.57 & 7.33 & 7.02 & - & - & - \\
$\mathrm{Py} / \mathrm{Lu}$ Para & - & 7.99 & 7.78 & 7.54 & - & - & - \\
$\mathrm{N}-\mathrm{H}_{2}$ & 4.20 & 4.96 & 4.76 & 5.03 & 5.04 & 4.63 & 4.96 \\
$\alpha-\mathrm{C}_{\mathrm{Ala}}$ & 3.86 & 4.38 & 4.15 & 4.54 & 4.55 & 4.48 & 4.24 \\
$\alpha-\mathrm{C}_{\mathrm{Gly}}$ & 3.54 & 3.66 & 3.66 & 3.68 & 3.68 & 3.89 & 3.78 \\
$\alpha-\mathrm{C}_{\text {Trp/Asp }}$ & 3.64 & 3.52 & 3.14 & 3.86 & 3.87 & 3.62 & 3.96 \\
$\mathrm{OCH}_{3 \text { Gly }}$ & 3.40 & 3.44 & 3.54 & 3.53 & 3.52 & 2.33 & 3.40 \\
$\mathrm{Lu} \mathrm{CH}_{3}$ & 3.50 & 3.34 & 3.34 & 3.55 & 3.55 & 3.55 & 3.55 \\
$\beta-\mathrm{C}_{\text {Trp/Asp }}$ & - & - & 3.18 & 2.41 & - & - & - \\
$\mathrm{OC}\left(\mathrm{CH}_{3}\right)_{3 \text { Asp }}$ & 2.45 & 2.61 & 2.57 & 2.63 & 2.61 & 3.18 & 3.28 \\
$\beta-\mathrm{C}_{\mathrm{Ala}}$ & 2.35 & 2.40 & 2.41 & 2.46 & 2.45 & 1.44 & - \\
\hline
\end{tabular}

${ }^{*}$ Represents the minor species.

Table 3. Assigned ${ }^{13} \mathrm{C}-\mathrm{NMR}$ resonances for complexes 4, 8-11.

\begin{tabular}{cccccc}
\hline Chemical Shift (ppm) & $\mathbf{4}$ & $\mathbf{8}^{*}$ & $\mathbf{9}$ & $\mathbf{1 0}$ & $\mathbf{1 1}$ \\
\hline $\mathrm{C}=\mathrm{O}_{\text {Trp }} /$ Asp & 170.14 & 169.93 & 169.79 & 170.75 & 172.93 \\
$\mathrm{C}=\mathrm{O}_{\text {Ala }}$ & 185.17 & 185.45 & 177.03 & 176.26 & 178.24 \\
$\gamma-\mathrm{C}=\mathrm{O}_{\text {Asp }}$ & 175.91 & 175.9 & 172.89 & 172.58 & - \\
$\mathrm{C}=\mathrm{O}_{\text {Gly }}$ & 172.34 & 171.71 & 186.47 & n.d. & 186.55 \\
$\mathrm{OC}\left(\mathrm{CH}_{3}\right)_{3 \text { Asp }}$ & 79.93 & 80.14 & 80.47 & 82.32 & - \\
$\mathrm{OCH}_{3}$ Gly & 50.52 & 50.79 & 50.96 & 50.92 & 50.93 \\
$\alpha-\mathrm{C}_{\text {Trp }} /$ Asp & 56.55 & 56.50 & 55.81 & 40.16 & 59.58 \\
$\alpha-\mathrm{C}_{\text {Ala }}$ & 57.05 & 57.13 & 56.60 & 58.87 & 56.50 \\
$\alpha-\mathrm{C}_{\mathrm{Gly}}$ & 46.49 & 45.84 & 46.79 & 44.73 & 46.86 \\
$\beta-\mathrm{C}_{\text {Trp }} /$ Asp & 39.86 & 39.73 & 39.94 & 54.7 & 29.93 \\
$\mathrm{OC}(\mathrm{CH})_{3}$ Asp & 27.79 & 27.79 & 27.79 & 27.58 & - \\
$\beta-\mathrm{C}_{\text {Ala }}$ & 19.43 & 19.78 & 19.80 & 20.64 & 19.92
\end{tabular}

* Trp side chain and lutidine resonances found in experimental section. n.d.- -not observed. 
Table 4. Observed and assignment of ${ }^{13} \mathrm{C}$ NMR resonances for 4, 8-11 and corresponding calculated values.

\begin{tabular}{|c|c|c|c|c|c|c|c|c|c|c|}
\hline $\begin{array}{l}\text { Chemical } \\
\text { Shift (ppm) }\end{array}$ & $\begin{array}{c}4 \\
\text { (obs) }\end{array}$ & $\begin{array}{c}4 \\
(\text { calc })\end{array}$ & $\begin{array}{c}8 \\
\text { (obs) }\end{array}$ & $\begin{array}{c}8 \\
(\text { calc })\end{array}$ & $\begin{array}{c}9 \\
\text { (obs) }\end{array}$ & $\begin{array}{c}9 \\
(\text { calc })\end{array}$ & $\begin{array}{c}10 \\
\text { (obs) }\end{array}$ & $\begin{array}{c}10 \\
\text { (calc) }\end{array}$ & $\begin{array}{c}11 \\
\text { (obs) }\end{array}$ & $\begin{array}{c}11 \\
(\text { calc })\end{array}$ \\
\hline $\mathrm{C}=\mathrm{O}_{\operatorname{Trp}} / \mathrm{Asp}$ & 170.14 & 170.82 & 169.93 & 171.07 & 169.79 & 171.39 & 170.75 & 165.3 & 172.93 & 169.9 \\
\hline $\mathrm{C}=\mathrm{O}_{\mathrm{Ala}}$ & 185.17 & 181.86 & 185.45 & 182.5 & 177.03 & 177.63 & 176.26 & 176.5 & 178.24 & 177.11 \\
\hline$\gamma-\mathrm{C}=\mathrm{O}_{\mathrm{Asp}}$ & 175.91 & 171.72 & 175.9 & 174.71 & 172.89 & 172.31 & 172.58 & 172.4 & - & - \\
\hline $\mathrm{C}=\mathrm{O}_{\mathrm{Gly}}$ & 172.34 & 171.34 & 171.71 & 173.3 & 186.47 & 186.23 & n.d. & 187.8 & 186.55 & 185.82 \\
\hline
\end{tabular}

Table 5. Summary of infrared data for 1-4, 8-11.

\begin{tabular}{ccccccccc}
\hline Frequency $\left(\mathbf{c m}^{-\mathbf{1}}\right)$ & $\mathbf{1}$ & $\mathbf{2}$ & $\mathbf{3}$ & $\mathbf{4}$ & $\mathbf{8}$ & $\mathbf{9}$ & $\mathbf{1 0}$ & $\mathbf{1 1}$ \\
\hline$v\left(\mathrm{NH}_{2}\right)$ & 3370 & $3375^{*}$ & $3370 *$ & 3234 & 3223 & 3245 & 3239 & 3286 \\
$v(\mathrm{NH})$ & 3314 & 3304 & 3297 & 3138 & 3100 & 3129 & 3121 & 3235 \\
$v(\mathrm{C}=\mathrm{O})$ & & & & & & & & \\
$\mathrm{O}^{t} \mathrm{Bu}$ & 1725 & 1743 & - & 1723 & 1732 & 1729 & 1732 & - \\
$\mathrm{OMe}$ & $1759 *$ & $1757^{*}$ & 1749 & $1748^{*}$ & $1750 *$ & 1541 & 1551 & 1554 \\
$\mathrm{Amide} \mathrm{I}$ & 1670 & 1659 & 1655 & 1585 & 1604 & 1608 & 1590 & 1598 \\
$v(\mathrm{C}-\mathrm{O})$ & & & & 1570 & 1582 & 1584 & 1567 & 1569 \\
$\mathrm{O}^{t} \mathrm{Bu}$ & 1250 & 1254 & - & 1254 & 1250 & 1253 & 1258 & - \\
$\mathrm{OMe}$ & 1213 & 1212 & 1213 & 1210 & 1210 & 1205 & 1207 & 1207 \\
$v(\mathrm{O}-\mathrm{C})$ & & & & & & & & \\
$\mathrm{O}$ & 1155 & 1155 & - & 1148 & 1147 & 1145 & 1155 & - \\
$v(\mathrm{M}-\mathrm{N})$ & 1250 & 1254 & - & 573 & 568 & 573 & 573 & 568 \\
& & & & 548 & 548 & 548 & 533 & 534 \\
\hline * Denotes shoulder absorption. & & & & & & & &
\end{tabular}

Table 6. Comparative frequencies $\left(\mathrm{cm}^{-1}\right)$ for $v(\mathrm{C}=\mathrm{O})$ vibrational modes observed versus DFTcalculated for 4, 8-11. The $\Delta$ values show the deviation between observed and calculated DFT values.

\begin{tabular}{ccccc}
\hline Complex & $\boldsymbol{v}(\mathbf{C}=\mathbf{O}) \mathbf{O}^{t} \mathbf{B u}$ & $\boldsymbol{v}(\mathbf{C}=\mathbf{O})$ OMe & $v(\mathbf{C}=\mathbf{O})$ Amide I & $v(\mathbf{C}=\mathbf{O})$ Amide I \\
\hline $\mathbf{4}$ Obs & 1723 & 1748 & 1585 & 1570 \\
DFT & 1767 & 1782 & 1659 & 1639 \\
$\Delta$ & 44 & 34 & 74 & 69 \\
$\mathbf{8}$ Obs & 1732 & 1750 & 1604 & 1582 \\
DFT & 1749 & 1790 & 1664 & 1642 \\
$\Delta$ & 17 & 40 & 60 & 60 \\
$\mathbf{9}$ Obs & 1729 & 1541 & 1608 & 1584 \\
DFT & 1757 & 1677 & 1666 & 1652 \\
$\Delta$ & 28 & 136 & 58 & 68 \\
$\mathbf{1 0}$ Obs & 1732 & 1551 & 1590 & 1567 \\
DFT & 1784 & 1674 & 1653 & 1653 \\
$\Delta$ & 52 & 123 & 63 & 86 \\
$\mathbf{1 1}$ Obs & - & 1554 & 1598 & 1569 \\
DFT & - & 1652 & 1677 & 1662 \\
$\Delta$ & - & 98 & 79 & 93 \\
\hline
\end{tabular}

Quantum chemical calculations at the DFT level were used to aid the spectral interpretation. To correctly assign coordination geometries, similarities and differences in the complexes' ${ }^{13} \mathrm{C}-\mathrm{NMR}$ chemical shifts, and shifts in infrared frequencies of major bands were examined. Observed values were compared to calculated chemical shifts and vibrational frequencies of the DFT-optimized structural models (Tables 4 and 6).

\subsubsection{H- and ${ }^{13} \mathrm{C}-\mathrm{NMR}$ Spectroscopy}

The ${ }^{1} \mathrm{H}$ and ${ }^{13} \mathrm{C}$ spectra of 4-11 were obtained in DMSO- $d_{6}$ and the resonances were assigned with the aid of COSY and HSQC measurements (Figures S1-S6). DMSO- $d_{6}$ was 
selected since it allowed the monitoring of the $\mathrm{NH}_{2}$ protons, and the complexes were highly soluble.

The coordinated amine/amide backbone was a commonality of 4-11; this coordination was established in the proton NMR (Table 2) with the appearance of the amino protons as two triplets between $\sim 5.0$ and $3.8 \mathrm{ppm}$, while the amide protons, located $\sim 8.40-8.10 \mathrm{ppm}$, disappeared. Generally, compared to the free ligands 1-3 (Table S1), the $\alpha$-C protons shifted upfield, whereas Ala $\alpha$-C protons tended to shift the most and had the largest range of movement, as seen in Figure 5. This behavior was expected considering the Asp amide was trans to the fourth coordination site, counting clockwise from the anchoring amine group; thus, the magnetic environment of these protons changed more significantly.

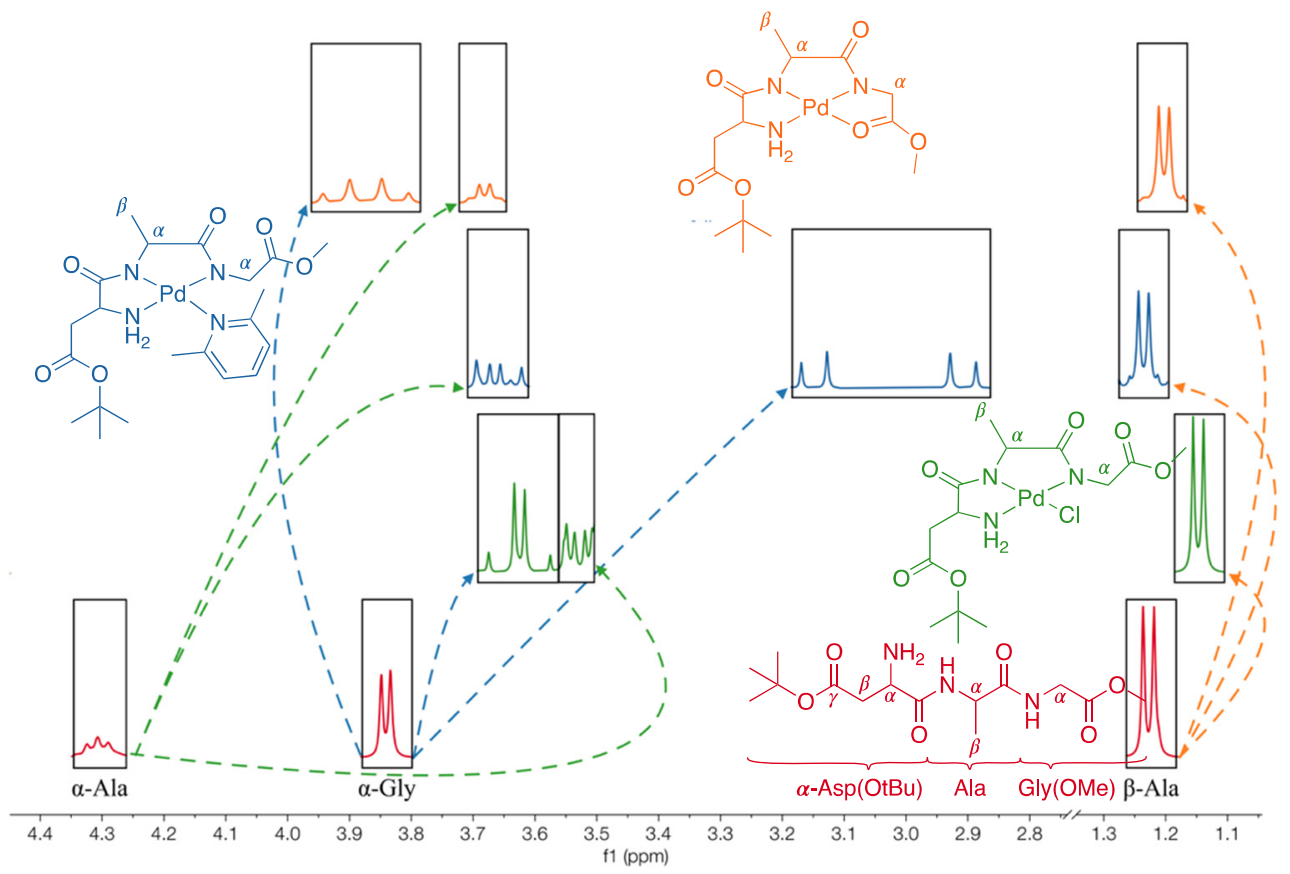

Figure 5. Progression of select ${ }^{1} \mathrm{H}-\mathrm{NMR}$ resonances of $\mathbf{1}$ (red) to 4 (green), 8 (blue), and 9 (orange).

The ${ }^{1} \mathrm{H}-\mathrm{NMR}$ resonances for 4 generally shifted upfield the most compared to 7 9, presumably since this is the only negatively charged species, and the chloride's $\pi$ donation to palladium effectively increased shielding around the ligand. The coordination of pyridine to 4 resulted in the amino, Asp, and Ala $\alpha$-C protons all shifting downfield (Table 2,7 ), which is explained by pyridine $\pi$-back-bonding, resulting in metal deshielding. However, the Gly $\alpha-C$ and methyl ester protons shifted further upfield; one explanation for this is $\pi$ interactions with neighboring pyridine. Heating 7 overnight at $110{ }^{\circ} \mathrm{C}$ did not show any observable changes in the NMR. The complex with the coordinated $\mathrm{Lu}(8)$ had slightly different spectroscopic behaviors compared to 7 . Notably, a large upfield shift of the $\mathrm{NH}_{2}$ protons $(\Delta \delta 0.20$ and $0.23 \mathrm{ppm})$. In 7 , the Gly protons experienced the largest shielding effects of the series, appearing with a large coupling constant of $\sim 96 \mathrm{~Hz}$ with resonances at 3.14, and $2.91 \mathrm{ppm}$ (Figure 5). This is further evidence of a $\pi$ interaction between the lutidine and the glycine moiety. Upon heating 8 overnight at $110{ }^{\circ} \mathrm{C}$, a new species was observed, where the Lu was no longer coordinated. This new species matched the spectrum of 9.

Support for the coordination mode of $\mathbf{9}$ was established in part by examining the ${ }^{1} \mathrm{H}-\mathrm{NMR}$. The appearance of the $\mathrm{NH}_{2}$ protons at 4.76 and $5.03 \mathrm{ppm}$ established the amine coordination. The Asp $\alpha-\mathrm{C}$ proton appeared at about the same resonances as in one. However, the Ala $\alpha-\mathrm{C}$ protons experienced a large upfield shift, supporting the Asp amide coordination. The Gly protons only shifted by $0.03 \mathrm{ppm}$ compared to one, but the Gly coupling pattern changed from a doublet to a quadruplet, signifying Ala amide coordination as seen in Figure 5. The small change in resonances is explained with carbonyl 
oxygen coordination. A carbonyl group was a $\pi$-acceptor ligand, deshielding the metal. An argument for a coordinated ester via carboxylate oxygen was not supported, given the small change in the methyl ester chemical shift.

The ${ }^{1} \mathrm{H}$-NMR spectrum of $\mathbf{1 0}$ was poorly resolved owing to the lability of the sixmembered ring. However, important information regarding coordination geometry was gleaned from the 2D-NMR coupling patterns and discernible resonance positions. Elevated temperature ${ }^{1} \mathrm{H}-\mathrm{NMR}$ experiments $(330 \mathrm{~K})$ were performed to improve the spectral resolution. Coordination of the amine was evidenced by the $\mathrm{NH}_{2}$ resonances at 4.63 and $4.48 \mathrm{ppm}$. Side chain methylene protons of the N-terminal amino acid (Asp or Trp) were a characteristic feature of the ligands $1-3$. These protons were diastereotopic and when recorded in DMSO- $d_{6}$, appeared as a pair of doublet of doublets. This is because they were in different magnetic environments with different vicinal coupling. For 4-9, these protons were outside a chelate ring and showed similar coupling constants as the ligands. However, 10 (Table 2) enclosed the methylene protons in a six-membered ring and they became an apparent quadruplet. Additionally, a large upfield shift of the $\alpha-C$ protons for Asp $(\Delta \delta 0.46 \mathrm{ppm})$, Ala $(\Delta \delta 0.42 \mathrm{ppm})$, and Gly $(\Delta \delta 0.21 \mathrm{ppm})$ confirmed the amine/amide backbone chelation.

In 11, the appearance of the $\mathrm{NH}_{2}$ protons at 4.96 and $4.24 \mathrm{ppm}$ confirmed the $\mathrm{N}$ terminus amine coordination, whereas the indole resonances were relatively unchanged, suggesting the $\mathrm{N}$-indole amine remained uncoordinated. Ala $(\Delta \delta 0.56 \mathrm{ppm})$ and $\operatorname{Trp}(\Delta \delta$ $0.11 \mathrm{ppm}) \alpha-\mathrm{C}$ protons shifted downfield and were in agreement with $\mathbf{9}$ and 10.

The ${ }^{13} \mathrm{C}$ NMR spectrum collected for the ligands 1-3 (Table S2) and complexes 4, 8-11 (Table 3) were tabulated and compared. Assignments for the carbon spectrum were aided by the 2D-NMR technique HSQC. As expected, all $\alpha$-carbons shifted downfield, while Ala $\alpha$-carbons underwent the largest downfield shifts and had the broadest range.

The most significant and difficult ${ }^{13} \mathrm{C}$ assignments belonged to the carbonyl carbons. In order to confidently assign these signals, DFT calculations were used to elucidate coordination modes and to calculate the ${ }^{13} \mathrm{C}$ chemical shifts. The calculations were based on the optimized geometries depicted in Figure 2. Table 4 shows a comparison of observed and calculated carbonyl ${ }^{13} \mathrm{C}$ chemical shifts, which were adjusted for systematic differences in shielding values. For $\mathbf{4}$ and $\mathbf{8}$, there was a decent agreement between the observed and calculated values for Gly and Asp esters, and Asp amides. However, the Ala amide showed a stronger deshielding than calculations suggested. The coordination of the ester carbonyl $\left(\mathrm{C}=\mathrm{O}_{\mathrm{Gly}}\right)$, observed in $\mathbf{9}$ and $\mathbf{1 1}$, was accompanied by a large downfield shift from $\sim 170$ (1-3) to $\sim 186 \mathrm{ppm}$, which was consistent with reported values [39]. Due to the lability of 10, this peak was not observed, even in the high temperature NMR experiment.

\subsubsection{Infrared Spectroscopy}

Infrared spectroscopic data were collected in $\mathrm{\kappa Br}$ discs and are detailed for ligands 1-3 and for complexes 4, 8-11 in Table 5 and Supplementary Materials Figure S7. Vibrational modes for the ligands and complexes were assigned with the aid of DFT calculations, based on relative value sets. Comparative values for observed and calculated carbonyl stretching bands for $\mathbf{9 - 1 1}$ are presented in Table 6 .

For 4, 8-11, the low energy shift of symmetric and asymmetric stretching modes for $\mathrm{NH}_{2}$ to energies typical of coordinated $\mathrm{N}_{\text {amino, }} \sim 3250-3100 \mathrm{~cm}^{-1}$, [40] confirmed amine coordination, and the Amide I bands, which were mostly $v(\mathrm{C}-\mathrm{N})$ shifted to low energy and combined with the Amide II bands; this supports the amine/amide backbone chelation. Additionally, palladium to nitrogen vibrational energies appeared and were consistent with reported values [40-43].

For 4 and 8, the methyl ester carbonyl band was still present at $\sim 1750 \mathrm{~cm}^{-1}$, indicating that the carbonyl was not coordinated. Lutidine coordination was confirmed for 8 with the appearance of an aromatic $v(C=C)$ band at $1471 \mathrm{~cm}^{-1}$ (free $\mathrm{Lu} 1481 \mathrm{~cm}^{-1}$ ) and by the shift of the out-of-plane $\mathrm{CH}$ band to a higher frequency $\left(787 \mathrm{~cm}^{-1}\right)$ compared to that of the free ligand $\left(770 \mathrm{~cm}^{-1}\right)$ [40]. Pd-Cl vibrations appeared at far-IR frequencies and 
were not observable. Compared to 4 and 8 , the spectrum for 9 had a strong distinct band at $1541 \mathrm{~cm}^{-1}$, as seen in Table 6. Palladium complexes with similar ester coordination were synthesized and were reported to exhibit a large shift of the ester carbonyl stretching frequency to lower energies $[39,44]$ upon coordination. This indicates that the methyl ester carbonyl oxygen was coordinated to Pd, resulting in a lower energy shift of $\sim 200 \mathrm{~cm}^{-1}$. This assignment is supported by the calculated relative vibrational frequencies for this complex; a similar band was present in the spectra collected for $\mathbf{1 0}$ and 11, suggesting 9-11 had methyl ester carbonyl coordination. In addition, the methyl ester $v(\mathrm{C}-\mathrm{O})$ for 9-11 appeared to have a similar low energy shift of $\sim 7 \mathrm{~cm}^{-1}$.

\subsubsection{Mass Spectrometry}

MS spectra were obtained using ESI-MS in the negative ion scan for anions and the positive ion scan for neutral or positive ions (Supplementary Materials Figures S1b, S3b, $\mathrm{S} 4 \mathrm{c}, \mathrm{S} 5 \mathrm{c}$ and S6c). The found ion peaks were simulated with expected isotope patterns to confirm the composition of the compound found compared to the expected composition. Complexes 4-6 were obtained in the negative ion mode where the major isotope pattern observed was the $\left[\mathrm{Pd}\left\{\mathrm{Asp}\left(\mathrm{O}^{t} \mathrm{Bu}\right) \mathrm{AlaGly}(\mathrm{OMe})\right\} \mathrm{Cl}\right]^{-}$ion, confirming these complexes were the anionic chloride species. The major isotope pattern for the neutral complexes was the $\left[\mathrm{M}+\mathrm{Na}^{+}\right]^{+}$species. The isolated compounds showed an excellent match with less than 2 ppm variation in simulated vs. found values.

\subsection{Reactivity Studies}

\subsubsection{Sulfur Reagents}

Palladium is a soft Lewis acid metal and is, therefore, thiophilic. Reacting palladium tripeptide complexes with episulfides could be a way to open coordination on the tetradentate complex and activate the metal. The tetracoordinated $\mathrm{Pd}$ (II) complex with $\mathrm{NS}_{3}$ donor sets was reported able to catalytically cleave a $\mathrm{C}\left(\mathrm{sp}_{2}\right)-\mathrm{I}$ bond to form a $\mathrm{Pd}-\mathrm{I}$ bond despite coordination saturation [45], suggesting a single coordination site could be sufficient for a sulfur transfer reaction or organosulfur polymerization. For 9-11, after the initial episulfide coordination, several outcomes were conceivably possible. Either (a) the sulfur could coordinate in an oxidative addition reaction and form a palladium(IV) sulfur complex, expelling cyclohexene; (b) $\mathrm{Pd}(\mathrm{II})$ would react with the sulfur substrates to coordinate sulfur and a second episulfide could react with the coordinated episulfide to form a polythioether; (c) a catalytic sulfur transfer could occur, expel sulfur as $S_{n}$ and $\mathrm{Pd}(\mathrm{II})$ coordinate to the resulting olefin [46].

Cyclohexene sulfide was reacted with complexes 9-11 and the results were monitored by ${ }^{1} \mathrm{H}-\mathrm{NMR}$ to the determine conversion of thiirane to alkene in an overall reaction seen in Scheme 2 (Figures S8 and S9). The percent conversion to cyclohexene is detailed in Figure 6 as a function of time.

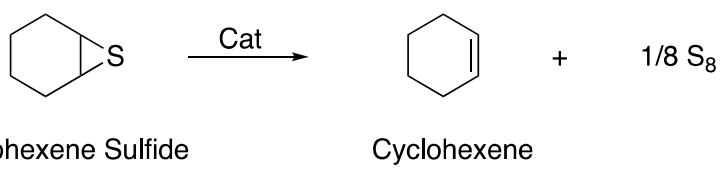

Scheme 2. Catalytic conversion of cyclohexene sulfide to cyclohexene. 


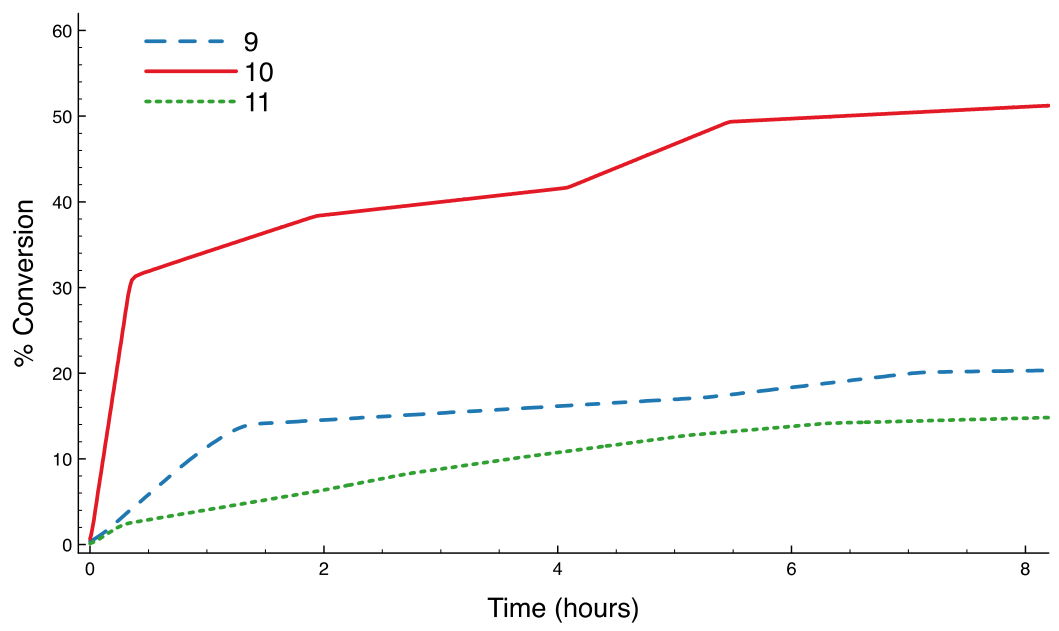

Figure 6. Percent catalytic conversion of cyclohexene sulfide to cyclohexene with $3 \mathrm{~mol} \%$ complexes 9, 10, and 11, monitored via ${ }^{1} \mathrm{H}-\mathrm{NMR}$ spectroscopy.

For 9, a quick conversion of cyclohexene sulfide to cyclohexene reached up to $20 \%$, which slowed down after $\sim 30 \%$ cyclohexene formation was observed. The deactivation of the catalyst was confirmed at $\sim 30 \mathrm{~h}$. Complex $\mathbf{1 0}$ showed a much higher conversion to cyclohexene, with conversion reaching $>50 \%$ after $24 \mathrm{~h}$ before the deactivation of the catalyst. The lowest conversion was seen with 11, where initial conversion was slow and plateaued at $\sim 15 \%$. For the most relevant industrial catalysts, the turnover frequency (TOF, mol product $/ \mathrm{mol}$ catalyst $\mathrm{x}$ time) was in the range $36-360,000 \mathrm{~h}^{-1}$ [47]. The best TOF for 9-11 was observed for 10 ( $3 \mathrm{~mol} \%$ ) with a value of $2.59 \mathrm{~h}^{-1}$. Post-reaction work-up of the ${ }^{1} \mathrm{H}-\mathrm{NMR}$ sample showed that the ligand was partially demetallized. The sample from the catalytic reaction of $\mathbf{1 0}$ with cyclohexene sulfide was examined post-reaction. The solution was filtered, taken to dryness under reduced pressure, and ${ }^{1} \mathrm{H}-\mathrm{NMR}$ was recorded. The NMR spectrum of the post-catalytic solution exhibited resonances for freeligand 2, confirming that $\mathbf{1 0}$ did not remain intact (Supplementary Materials Figures S8 and S9). Solubility based separation of the ligand and the viscous material that formed was performed. The ${ }^{1} \mathrm{H}-\mathrm{NMR}$ of the viscous material was in agreement with the polythioether formation [46]. The reactions with episulfides, therefore, indicated that both alkene and polythioether may form; although these results were preliminary. It was noted that the cyclohexene formed did not coordinate to the metal center in these reactions.

To ensure the reaction conversion was not spontaneous, a blank sample maintaining same conditions but omitting the complex was run. That reaction resulted in no identifiable alkene formation for commensurate times as the runs, including complexes.

\subsubsection{Olefins}

Palladium is known to coordinate to ethylene in an $\eta^{2}$ fashion [48]. The $\mathrm{Pd}(\mathrm{II})$ complex with a tridentate ligand and a hemilabile methoxy ligand was shown to catalyze ethylene oligomerization [49]. The intention here was to study the availability of the 4th coordination site for reactivity and hemi-labile coordination, by either removing the chloride or lutidine ligand or by opening the chelate on the C-terminus ester carbonyl, thereby accessing the 4 th coordination site that could serve as a reaction site.

To examine whether these complexes are good candidates for reactions with olefins; ethylene reactivity studies were performed and monitored with ${ }^{1} \mathrm{H}-\mathrm{NMR}$ spectroscopy (Figure S10). The general procedure was to dissolve 9 in DMSO- $d_{6}$ and record the spectrum, bubble ethylene directly into the NMR tube and record the spectra again. Free ethylene resonance was observed at $5.14 \mathrm{ppm}$, in DMSO- $d_{6}$ and it was concluded that no reaction took place. The addition of a proton source was attempted to see the reaction chemistry. Trifluoroacetic acid (TFA) and triflic acid (TFMS) were selected as proton sources, since TFA is a weak acid and TFMS a strong acid, and neither have interfering proton resonances. 
Portions ranging from $\sim 10$ to 20 -fold excess of TFA or TFMS were added to nine and ethylene mixtures, and the spectra were recorded again. It was assumed that the palladium complexes would be fairly tolerant of an acidic environment, due to the fact that Pd(II) can chelate peptide amide bonding at low $\mathrm{pH}$ values [17].

Increasing volumes of TFA to a solution of $\mathbf{9}$ and ethylene resulted in the demetallation of the ligand, where above a $\sim 15$-fold excess, the spectra revealed complete demetallation and protonation of the $\mathrm{N}$ functional groups in the presence of acidic protons. In parallel, increased amounts of TFA resulted in the oxidation of ethylene to form acetaldehyde (See Scheme 3). The formation of acetaldehyde increased proportionally with the quantity of TFA and appeared catalyzed by $\operatorname{Pd}(\mathrm{II})$ after dissociation from the ligand. With a reversed order of addition, first TFA then ethylene, acetaldehyde only formed once both TFA and ethylene were present. A blank spectrum of TFA and ethylene in DMSO confirmed that this was not a spontaneous reaction.

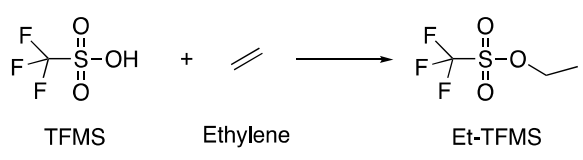

Scheme 3. Oxidation of ethylene to form acetaldehyde catalyzed by pd(II).

The triflic acid (tfms) was substituted for tfa to determine if a different proton source produces the same product; dissimilar to tfa, tfms is non-coordinating. The addition of excess TFMS also resulted in the demetallation of the ligand, and again the oxidation of ethylene was observed by the formation of acetaldehyde signals. This reaction also formed a second product that was likely ethyl trifluoromethanesulfonate (Scheme 4), which is known to form from triflic acid in the presence of ethylene [50,51].

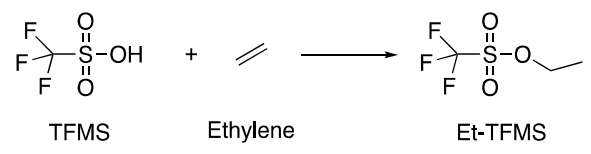

Scheme 4. Spontaneous reaction between trifluoromethanesulfonate and ethylene to form ethyl trifluoromethanesulfonate.

The ${ }^{13} \mathrm{C}-\mathrm{NMR}$ spectra for this experiment revealed that the addition of $20-30 \mu \mathrm{L}$ TFA did not result in any significant changes to the signals of 9; although this amounted to 10 to 15-fold excess TFA, the signature quadruplets for TFA at $\sim 158$ and 115 ppm were not present in the spectrum. This could be related to the volatility of this reagent and the length of ${ }^{13} \mathrm{C}$ experiments. When more TFA $(40 \mu \mathrm{L})$ or TFMS $(40 \mu \mathrm{L})$ are added, the ${ }^{13} \mathrm{C}$ signals were affected significantly. This supports the findings that demetallation occurred. The confirmation of Et-TFMS formation was seen in the corresponding ${ }^{13} \mathrm{C}$ signals at 15.67 and 73.08 , respectively. The formation of an aldehyde signal at $201.25 \mathrm{ppm}$ and the appearance of a peak at 31.10 ppm supports the assertion that acetaldehyde was formed.

Complex 10, with the more labile six-membered ring, was also reacted with TFA and ethylene. It was expected in a direct comparison with 9; complex 10 would show a higher reactivity. Upon TFA addition to 10 , the ${ }^{1} \mathrm{H}-\mathrm{NMR}$ changed dramatically. Again, partial demetallation and amide protonation occurred. However, a large shift in the Asp moiety, still coupled with the Asp $\mathrm{NH}_{2}$, indicated that the amine was still coordinated. After the addition of ethylene, the formation of acetaldehyde was observed in about 10\% quantitatively relative to the complex. The ${ }^{13} \mathrm{C}-\mathrm{NMR}$ spectrum for this experiment was not informative due to the lability of the complex. The complexes 9-11 were; therefore, not amenable to ethylene coordination despite its stronger ligand properties compared to the carbonyl ester. 


\subsubsection{Derivatives of $\mathrm{CO}_{2}$ and $\mathrm{CO}$}

Carbonylation reactions are typically performed using $\mathrm{CO}$ in conjunction with various monomers, including olefins [52-54] and alcohols [55] under high pressure to yield various carboxylic acid derivatives. In order to avoid the use of carbon monoxide as $\mathrm{C}_{1}$-feedstock, $\mathrm{CO}$ surrogates may be used. Chief among these $\mathrm{CO}$ alternative are formic acid derivatives [56].

In order to examine whether these complexes were candidates for carbonyl coordination, the activation of methyl formate was investigated. A stock solution of methyl formate in DMF was added to solutions of 9-10 in a 1.1:1 ratio, with the intent of monitoring the electronic spectra. However, upon mixing, the formation and precipitation of $\mathrm{Pd}$ black occurred immediately. Coordination of this formate was, therefore, not successful, although these results did not accurately predict its potential performance in carbonylation reactions since carbonylation reactions require a protic solvent or a proton source as well as a base [56]. Acidic conditions such as employed in the Wacker process led to the reductive elimination and reduction to $\mathrm{Pd}(0)$.

\section{Discussion}

The synthesis and characterization of tetradentate tripeptide complexes 9-11 with Cterminal carbonyl ester coordination were reported. The complexes were designed to form hemilabile ligand chelates that could open and close depending on the surrounding system. However, this coordination mode formed weaker sigma bonds which made it inherently more difficult to form in the presence of a more favorable ligands. The development of a non-aqueous synthesis strategy, using a non-nucleophilic base was instrumental in the formation of neutral tetradentate palladium complexes with $\kappa^{4}\left[\mathrm{NH}_{2}, \mathrm{~N}, \mathrm{~N},=\mathrm{O}\right]$ coordination Charged ester carbonyl palladium complexes are reported in the literature, [39] but neutral complexes appear to be much rarer. The use of this synthetic strategy offers the possibility to facilitate the coordination of ester carbonyl oxygen to other metal centers.

$\mathrm{Pd}(\mathrm{II})$ complexes with tridentate tripeptides 4-6 were also isolated. These complexes were anionic and had a chloride ligand. Ligand exchange reactions of 4 successfully displaced the chloride ligand with lutidine (8) and pyridine (7). However, lutidine was a weaker nucleophile and was sterically more hindered than pyridine, resulting in were incorporation. Lutidine exhibited partial thermal lability resulting in $\sim 30 \%$ dissociation upon heating to form complex 9.

The development of this class of complexes was meant to achieve maximum organosolubility, to carry out reactions in non-coordinating solvents. Despite $\mathbf{9}$ and $\mathbf{1 0}$ having multiple functional groups, including the methyl and $t$-butyl esters, and an indole present 11, these complexes were relatively insoluble. Consequently, characterization and reaction studies were carried out in coordinating solvents.

Complexes 9-11 Ware able to catalytically transfer sulfur atoms, where $\mathbf{1 0}$ outperformed $\mathbf{9}$ and $\mathbf{1 1}$ in terms of TOF before deactivation. The catalytic studies of synthesized $\mathrm{Pd}$ complexes with cyclohexene sulfide showed that 10, with its more labile six-membered chelate, was more reactive. The study confirmed that the Pd complexes are capable of catalyzing the reaction of cyclohexene sulfide to cyclohexene. The complexes also appeared to form polythioethers but were not sufficiently active to be considered more than modest catalysts for sulfur transfer compared to a recent report of TOF of $698 \mathrm{~h}^{-1}$ for a similar reaction [57].

In the presence of $\mathrm{Pd}(\mathrm{II})$, ethylene was oxidized to form the acetaldehyde in the well-known Wacker Process (WP) [58]. The reactivity studies of $\mathbf{9}$ and $\mathbf{1 0}$ with ethylene showed the activation of the ethylene group only with the addition of a proton source. After the addition of $\sim 10$-fold excess acid to the complex and olefin, demetallation was observed. The degree of demetallation increased with the amount of acid, and the amount of acetaldehyde formed also increased. It was unclear if the formation of acetaldehyde was limited by the number of acidic protons or the oxidizing agent, namely, trace amounts of water. Complexes $\mathbf{9}$ and $\mathbf{1 0}$ both exhibited a modest ability to convert ethylene to 
acetaldehyde, but it was unclear if this was due solely to ligand demetallation. Tripeptide palladium complexes synthesized in this work appeared susceptible to reduction to $\operatorname{Pd}(0)$ in the presence of $\mathrm{CO}$ and $\mathrm{CO}$ surrogates.

An interesting outcome was that demetallation was a recurring theme and olefin coordination did not take place. The ligand donors were sigma donors only and may have led to a very electron-rich metal center for lower oxidation states. The carbonyl ester coordination appeared stronger than presumed as was borne out in comparison of the reported hemilabile Pd-OMe bond distance of 2.178(3) $\AA$ [49] and the calculated distance of $2.109 \AA$. Considering the carbonyl oxygen donor may serve as a $\pi$ acceptor and an electron, a rich metal center may relieve its electron density through this bond.

\section{Materials and Methods}

Reagents used were purchased from Sigma-Aldrich and used without further purification unless otherwise stated. Solvents were purchased from Sigma-Aldrich and were distilled under nitrogen and dried using standard methods [59]. Ligands $\mathbf{1}-\mathbf{3}$ were prepared as outlined in previous work [31]. $\left[\mathrm{Pd}\left(\mathrm{CH}_{3} \mathrm{CN}\right)_{2} \mathrm{Cl}_{2}\right]$ was prepared according to a published procedure [60].

Infrared spectra were recorded on a Nicolet Avatar 360 FT-IR (E.S.P.) spectrophotometer (Thermo Fisher Scientific, Waltham, MA, USA) using $\kappa$ Br pellets. The ${ }^{1} \mathrm{H}, \mathrm{COSY}$, and ${ }^{13} \mathrm{C}$ nuclear magnetic resonance spectra were recorded at ambient temperature on a Bruker AVANCE $400 \mathrm{MHz}$ spectrometer (Bruker, Billerica, MA, USA) at 400 and 101 $\mathrm{MHz}$, respectively. Solvents used were $\mathrm{D}_{2} \mathrm{O}, \mathrm{DMSO}-\mathrm{d}_{6}$, and $\mathrm{CDCl}_{3}$. Electronic spectra were obtained using either Varian Cary 100 Bio spectrophotometer (Agilent, Santa Clara, CA, USA) or PerkinElmer Lambda 25 UV/Vis spectrophotometer (Thermo Fisher Scientific, Waltham, MA, USA). Mass spectra were recorded on a micrOTOF-Q spectrometer (Bruker, Billerica, MA, USA), equipped with E-spray atmospheric pressure ionization chamber (ESI). Elemental analyses were obtained from Midwest Microlab, Indianapolis, IN, USA.

\subsection{Synthesis}

\subsection{1. $\mathrm{K}\left[\mathrm{Pd}\left\{\alpha-\mathrm{Asp}\left(\mathrm{O}^{t} \mathrm{Bu}\right)\right.\right.$ AlaGly $\left.\left.(\mathrm{OMe})\right\} \mathrm{Cl}\right](4)$}

$\mathrm{K}_{2} \mathrm{PdCl}_{4}(0.040 \mathrm{~g}, 0.136 \mathrm{mmol})$ and $1(0.050 \mathrm{~g}, 0.136 \mathrm{mmol})$ were dissolved in $\mathrm{H}_{2} \mathrm{O}$ $(5 \mathrm{~mL})$ and $\mathrm{KOH}$ was added until $\mathrm{pH}=6.5$. Solution was stirred overnight under $\mathrm{N}_{2}$. The $\mathrm{H}_{2} \mathrm{O}$ was removed in vacuo and the product was isolated by dissolving in $\mathrm{EtOH}$ and filtering $(0.055 \mathrm{~g}, 98.2 \%):{ }^{1} \mathrm{H}-\mathrm{NMR}\left(400 \mathrm{MHz}, \mathrm{DMSO}-d_{6}\right) \delta 4.20$ (dd, $\left.1 \mathrm{H}, \mathrm{NH}_{\mathrm{Asp}}\right), 3.84(\mathrm{~d}$, $\left.1 \mathrm{H}, \mathrm{NH}_{\mathrm{Asp}}\right), 3.69-3.57\left(\mathrm{~m}, 2 \mathrm{H}, \alpha-\mathrm{H}_{\mathrm{Gly}}\right), 3.56-3.51\left(\mathrm{~m}, 1 \mathrm{H}, \alpha-\mathrm{H}_{\mathrm{Ala}}\right), 3.50\left(\mathrm{~s}, 3 \mathrm{H},-\mathrm{OCH}_{3 \mathrm{Gly}}\right)$, 3.43-3.36 (m, 1H, $\left.\alpha-\mathrm{H}_{\mathrm{Asp}}\right), 2.48-2\left(\mathrm{~m}, 1 \mathrm{H}, \beta-\mathrm{H}_{\mathrm{Asp}}\right), 2.35-2.29\left(\mathrm{~m}, 1 \mathrm{H}, \beta-\mathrm{H}_{\mathrm{Asp}}\right), 1.40(\mathrm{~s}$, 9H, $-\mathrm{O}\left(\mathrm{CH}_{3}\right)_{3}$ Asp $), 1.15$ (d, 3H, $\left.\beta-\mathrm{H}_{\mathrm{Ala}}\right) . \mathrm{IR}(\mathrm{KBr}) \mathrm{cm}^{-1}: 3315,3234(\mathrm{~b}, v(\mathrm{~N}-\mathrm{H})), 1723$ (s, $v(\mathrm{C}=\mathrm{O})), 1585(\mathrm{~s}, v(\mathrm{C}=\mathrm{O})), 1570(\mathrm{~s}, \mathrm{v}(\mathrm{C}-\mathrm{N})), 1254(\mathrm{~s}, v(\mathrm{C}-\mathrm{O})), 1210(\mathrm{~s}, \mathrm{v}(\mathrm{C}-\mathrm{O})), 1148(\mathrm{~s}$, $v(\mathrm{C}-\mathrm{O}))$. UV-VIS $\left(\mathrm{H}_{2} \mathrm{O}\right): \varepsilon_{\mathrm{X}}$ MS (ESI/Negative); MW: $\left(\mathrm{C}_{14} \mathrm{H}_{23} \mathrm{~N}_{3} \mathrm{O}_{6} \mathrm{PdCl}\right)=471.2230, \mathrm{~m} / z$ found $($ calc $)=472.0311(472.0313)\left[\mathrm{M}^{-}\right]$.

\subsection{2. $\left(\mathrm{Et}_{3} \mathrm{~N}\right)\left[\mathrm{Pd}\left\{\alpha-\mathrm{Asp}\left(\mathrm{O}^{t} \mathrm{Bu}\right) \mathrm{AlaGly}(\mathrm{OMe})\right\} \mathrm{Cl}\right](5)$}

$\mathrm{Pd}\left(\mathrm{CH}_{3} \mathrm{CN}\right)_{2} \mathrm{Cl}_{2}(0.076 \mathrm{~g}, 0.297 \mathrm{mmol})$ and $\mathbf{1}(0.097 \mathrm{~g}, 0.297 \mathrm{mmol})$ were dissolved in dry THF ( 20 mL) and triethylamine $(0.08 \mathrm{~mL}, 0.585 \mathrm{mmol})$ was added. The reaction was stirred overnight under Ar. Solution was filtered through celite and removed in vacuo. Seven-fold excess $\mathrm{Et}_{3} \mathrm{NCl}$ salt (crude yield $0.097 \mathrm{~g}$ ): ${ }^{1} \mathrm{H}-\mathrm{NMR}\left(400 \mathrm{MHz}\right.$, DMSO- $\left.d_{6}\right) \delta 4.21$ $\left(\mathrm{dd}, 1 \mathrm{H}, \mathrm{NH}_{\mathrm{Asp}}\right), 3.85\left(\mathrm{t}, 1 \mathrm{H}, \mathrm{NH}_{\mathrm{Asp}}\right), 3.6-3.56\left(\mathrm{~m}, 2 \mathrm{H}, \alpha-\mathrm{H}_{\mathrm{Gly}}\right), 3.56-3.51\left(\mathrm{~m}, 1 \mathrm{H}, \alpha-\mathrm{H}_{\mathrm{Ala}}\right)$, $3.50\left(\mathrm{~s}, 3 \mathrm{H},-\mathrm{OCH}_{3} \mathrm{Gly}\right), 3.40\left(\mathrm{~d}, 1 \mathrm{H}, \alpha-\mathrm{H}_{\mathrm{Asp}}\right), 3.08\left(\mathrm{q}, 14 \mathrm{H},-\mathrm{CH}_{2}\right.$ TEA $), 2.44\left(\mathrm{~d}, 1 \mathrm{H}, \beta-\mathrm{H}_{\mathrm{Asp}}\right)$, $2.33\left(\mathrm{dd}, 1 \mathrm{H}, \beta-\mathrm{H}_{\mathrm{Asp}}\right), 1.40\left(\mathrm{~s}, 9 \mathrm{H}, \mathrm{O}\left(\mathrm{CH}_{3}\right)_{3} \mathrm{Asp}\right), 1.23-1.13\left(\mathrm{~m}, 24 \mathrm{H}, \mathrm{O}\left(\mathrm{CH}_{3}\right)_{3}\right.$ Asp,$-\mathrm{CH}_{3}$ TEA $)$. IR (KBr) $\mathrm{cm}^{-1}$ : 3313, 3215 (b, v(N-H)), $1750(\mathrm{~s}, v(\mathrm{C}=\mathrm{O})), 1724(\mathrm{~s}, v(\mathrm{C}=\mathrm{O})), 1601(\mathrm{~s}, v(\mathrm{C}=\mathrm{O}))$, 1583 (s, v(C-N)), 1250 (s, v(C-O)), 1210 (s, v(C-O)), 1148 (s, v(C-O)). 


\subsection{3. $\left(\mathrm{PPh}_{4}\right)\left[\mathrm{Pd}\left\{\alpha-\mathrm{Asp}\left(\mathrm{O}^{\mathrm{t}} \mathrm{Bu}\right)\right.\right.$ AlaGly $\left.\left.(\mathrm{OMe})\right\} \mathrm{Cl}\right](6)$}

Excess $\mathrm{PPh}_{4} \mathrm{Cl}(0.128 \mathrm{~g}, 0.293 \mathrm{mmol})$ and crude $5(0.097 \mathrm{~g})$ were dissolved in dry THF. The resulting precipitate was filtered: ${ }^{1} \mathrm{H}-\mathrm{NMR}(400 \mathrm{MHz}$, Chloroform- $d) \delta 7.98-7.91(\mathrm{~m}$, $\left.4 \mathrm{H}, \mathrm{PPh}_{\text {para }}\right), 7.81\left(\mathrm{td}, 8 \mathrm{H}, \mathrm{PPh}_{\text {meta }}\right), 7.69-7.60\left(\mathrm{~m}, 8 \mathrm{H}, \mathrm{PPh}_{\text {ortho }}\right), 4.01-3.85\left(\mathrm{q}, 2 \mathrm{H}, \alpha-\mathrm{H}_{\mathrm{Gly}}\right)$, $3.96\left(\mathrm{~m}, 1 \mathrm{H}, \alpha-\mathrm{H}_{\mathrm{Ala}}\right), 3.64\left(\mathrm{~d}, 1 \mathrm{H}, \alpha-\mathrm{H}_{\mathrm{Asp}}\right), 3.58\left(\mathrm{~s}, 3 \mathrm{H}, \mathrm{OCH}_{3 \mathrm{Gly}}\right), 2.82\left(\mathrm{~d}, 1 \mathrm{H}, \beta-\mathrm{H}_{\mathrm{Asp}}\right), 2.50$ $\left(\mathrm{dd}, 1 \mathrm{H}, \beta-\mathrm{H}_{\mathrm{Asp}}\right), 1.42\left(\mathrm{~s}, 9 \mathrm{H},-\mathrm{O}\left(\mathrm{CH}_{3}\right)_{3} \mathrm{Asp}\right), 1.35\left(\mathrm{~d}, 3 \mathrm{H}, \beta-\mathrm{H}_{\mathrm{Ala}}\right) . \mathrm{IR}(\mathrm{KBr}) \mathrm{cm}^{-1}: 3314,3215$ $(\mathrm{b}, v(\mathrm{~N}-\mathrm{H})), 1750(\mathrm{~s}, v(\mathrm{C}=\mathrm{O})), 1724(\mathrm{~s}, \vee(\mathrm{C}=\mathrm{O})), 1601(\mathrm{~s}, v(\mathrm{C}=\mathrm{O})), 1583(\mathrm{~s}, v(\mathrm{C}-\mathrm{N})), 1250(\mathrm{~s}$, $v(\mathrm{C}-\mathrm{O})), 1194(\mathrm{~s}, v(\mathrm{C}-\mathrm{O})), 1138(\mathrm{~s}, v(\mathrm{C}-\mathrm{O}))$.

\subsection{4. $\mathrm{Pd}\left\{\alpha-\mathrm{Asp}\left(\mathrm{O}^{t} \mathrm{Bu}\right) \operatorname{AlaGly}(\mathrm{OMe})\right\}(\mathrm{Lu})(7)$}

$1(0.097 \mathrm{~g}, 0.293 \mathrm{mmol})$ and 2,6-lutidine $(0.064 \mathrm{~mL}, 0.585 \mathrm{mmol})$ were dissolved in THF $(20 \mathrm{~mL}) . \mathrm{Pd}(\mathrm{OAc})_{2}(0.066 \mathrm{~g}, 0.293 \mathrm{mmol})$ was added, and the reaction stirred under $\mathrm{Ar}$ overnight. The solution was filtered, the volume reduced in vacuo and precipitated out and washed with $\mathrm{Et}_{2} \mathrm{O}(0.113 \mathrm{~g} 88.3 \%):{ }^{1} \mathrm{H}-\mathrm{NMR}\left(400 \mathrm{MHz}\right.$, DMSO- $\left.d_{6}\right) \delta 7.78\left(\mathrm{t}, 1 \mathrm{H}, \mathrm{Lu}_{\text {para }}\right), 7.33$ $\left(\mathrm{dd}, 2 \mathrm{H}, \mathrm{Lu}_{\text {meta }}\right), 4.76\left(\mathrm{dd}, 1 \mathrm{H}, \mathrm{NH}_{\mathrm{Asp}}\right), 4.15\left(\mathrm{t}, 1 \mathrm{H}, \mathrm{NH}_{\mathrm{Asp}}\right), 3.71-3.60\left(\mathrm{~m}, 1 \mathrm{H}, \alpha-\mathrm{H}_{\mathrm{Ala}}\right), 3.54$ $\left(\mathrm{q}, 1 \mathrm{H}, \alpha-\mathrm{H}_{\mathrm{Asp}}\right), 3.34\left(\mathrm{~s}, 3 \mathrm{H},-\mathrm{OCH}_{3} \mathrm{Gly}\right), 3.18\left(\mathrm{~s}, 6 \mathrm{H}, \mathrm{Lu}_{\mathrm{CH} 3}\right), 3.14\left(\mathrm{~d}, 1 \mathrm{H}, \alpha-\mathrm{H}_{\mathrm{Gly}}\right), 2.91(\mathrm{~d}$, $\left.1 \mathrm{H}, \alpha-\mathrm{H}_{\mathrm{Gly}}\right), 2.57\left(\mathrm{dd}, 1 \mathrm{H}, \beta-\mathrm{H}_{\mathrm{Asp}}\right), 2.45-2.34\left(\mathrm{~m}, 1 \mathrm{H}, \beta-\mathrm{H}_{\mathrm{Asp}}\right), 1.41\left(\mathrm{~s}, 9 \mathrm{H},-\mathrm{O}\left(\mathrm{CH}_{3}\right)_{3}\right.$ Asp $)$, 1.23(m, 3H, $\left.\beta-\mathrm{H}_{\mathrm{Ala}}\right) ;{ }^{13} \mathrm{C}$ NMR $(101 \mathrm{MHz}, \mathrm{DMSO}) \delta 185.45\left(\mathrm{C}=\mathrm{O}_{\mathrm{Asp}}\right), 175.90\left(\mathrm{C}=\mathrm{O}_{\mathrm{Ala}}\right)$, $171.70\left(\mathrm{C}=\mathrm{O}_{\mathrm{Gly}}\right), 169.93\left(\gamma-\mathrm{C}=\mathrm{O}_{\mathrm{Asp}}\right), 160.12\left(\mathrm{Lu}_{\text {ortho }}\right), 159.69\left(\mathrm{Lu}_{\text {ortho }}\right), 139.08\left(\mathrm{Lu}_{\text {para }}\right), 122.72$ $\left(\mathrm{Lu}_{\text {meta }}\right), 122.60\left(\mathrm{Lu}_{\text {meta }}\right), 80.14\left(\mathrm{OC}\left(\mathrm{CH}_{3}\right)_{3 \mathrm{Asp}}\right), 57.13\left(\mathrm{OCH}_{3 \mathrm{Gly}}\right), 56.50\left(\alpha-\mathrm{C}_{\mathrm{Asp}}\right), 50.79(\alpha-$ $\left.\mathrm{C}_{\mathrm{Ala}}\right), 45.84\left(\alpha-\mathrm{C}_{\mathrm{Gly}}\right), 39.73\left(\beta-\mathrm{C}_{\mathrm{Asp}}\right), 27.79\left(\left(\mathrm{OC}\left(\mathrm{CH}_{3}\right)_{3 \mathrm{Asp}}\right), 25.86\left(\mathrm{Lu}_{\mathrm{CH} 3}\right), 25.77\left(\mathrm{Lu}_{\mathrm{CH} 3}\right)\right.$, $19.78\left(\beta-\mathrm{C}_{\text {Ala }}\right)$. IR $(\mathrm{KBr}) \mathrm{cm}^{-1}: 3303,3223(\mathrm{~b}, v(\mathrm{~N}-\mathrm{H})), 1750(\mathrm{~s}, v(\mathrm{C}=\mathrm{O})), 1732(\mathrm{~s}, v(\mathrm{C}=\mathrm{O}))$, $1604(\mathrm{~s}, v(\mathrm{C}=\mathrm{O})), 1582(\mathrm{~s}, v(\mathrm{C}-\mathrm{N})), 1250(\mathrm{~s}, v(\mathrm{C}-\mathrm{O})), 1200(\mathrm{~s}, v(\mathrm{C}-\mathrm{O})), 1147$ (s, v(C-O)). MS (ESI/Positive) MW: $\left(\mathrm{C}_{21} \mathrm{H}_{32} \mathrm{~N}_{4} \mathrm{O}_{6} \mathrm{Pd}\right)=542.9290, \mathrm{~m} / z$ found (calc) $=565.1254(565.1257)$ $\left[\mathrm{M}+\mathrm{Na}^{+}\right]$.

\subsection{5. $\mathrm{Pd}\left\{\alpha-\mathrm{Asp}\left(\mathrm{O}^{t} \mathrm{Bu}\right) \operatorname{AlaGly}(\mathrm{OMe})\right\}(9)$}

$1(0.331 \mathrm{~g}, 1.000 \mathrm{mmol})$ and Proton Sponge $(0.536 \mathrm{~g}, 2.500 \mathrm{mmol})$ were dissolved in THF $(20 \mathrm{~mL}) . \mathrm{Pd}(\mathrm{OAc})_{2}(0.224 \mathrm{~g}, 1.000 \mathrm{mmol})$ was added, and the reaction stirred under Ar for $5 \mathrm{~h}$. The solution was concentrated in vacuo and precipitated out with several additions of EtOAc and toluene. Product was recrystallize as a purple solid from acetonitrile and EtOAc $(0.295 \mathrm{~g}, 67.7 \%){ }^{1} \mathrm{H}-\mathrm{NMR}\left(400 \mathrm{MHz}, \mathrm{DMSO}-d_{6}\right) \delta 5.04\left(\mathrm{t}, 1 \mathrm{H}, \mathrm{NH}_{\mathrm{Asp}}\right), 4.55(\mathrm{t}, 1 \mathrm{H}$, $\left.\mathrm{NH}_{\mathrm{Asp}}\right), 3.95-3.79\left(\mathrm{~m}, 2 \mathrm{H}, \alpha-\mathrm{H}_{\mathrm{Gly}}\right), 3.68\left(\mathrm{q}, 1 \mathrm{H}, \alpha-\mathrm{H}_{\mathrm{Ala}}\right), 3.56\left(\mathrm{~s}, 1 \mathrm{H}, \alpha-\mathrm{H}_{\mathrm{Asp}}\right), 3.55(\mathrm{~s}, 3 \mathrm{H},-$ $\left.\mathrm{OCH}_{3 \mathrm{Gly}}\right), 2.61\left(\mathrm{dd}, 1 \mathrm{H}, \beta-\mathrm{H}_{\mathrm{Asp}}\right), 2.48-2.42\left(\mathrm{~m}, 1 \mathrm{H}, \beta-\mathrm{H}_{\mathrm{Asp}}\right), 1.42\left(\mathrm{~s}, 9 \mathrm{H},-\mathrm{O}\left(\mathrm{CH}_{3}\right)_{3} \mathrm{Asp}\right), 1.20$ $\left(\mathrm{d}, 3 \mathrm{H}, \beta-\mathrm{H}_{\mathrm{Ala}}\right) ;{ }^{13} \mathrm{C}$ NMR $(101 \mathrm{MHz}, \mathrm{DMSO}) \delta 177.03\left(\mathrm{C}=\mathrm{O}_{\mathrm{Asp}}\right), 172.89\left(\mathrm{C}=\mathrm{O}_{\mathrm{Ala}}\right), 169.79(\gamma-$ $\left.\mathrm{C}=\mathrm{O}_{\mathrm{Asp}}\right), 99.49\left(\mathrm{C}=\mathrm{O}_{\mathrm{Gly}}\right), 80.47\left(-\mathrm{OC}\left(\mathrm{CH}_{3}\right)_{3 \mathrm{Asp}}\right), 56.59\left(\mathrm{OCH}_{3 \mathrm{Gly}}\right), 55.80\left(\alpha-\mathrm{C}_{\mathrm{Asp}}\right), 50.93(\alpha-$ $\left.\mathrm{C}_{\mathrm{Ala}}\right), 46.79\left(\alpha-\mathrm{C}_{\mathrm{Gly}}\right), 39.94\left(\beta-\mathrm{C}_{\mathrm{Asp}}\right), 27.79\left(-\mathrm{OC}\left(\mathrm{CH}_{3}\right)_{3} \mathrm{Asp}\right), 19.80\left(\beta-\mathrm{C}_{\mathrm{Ala}}\right) . \mathrm{IR}(\mathrm{KBr}) \mathrm{cm}^{-1}$ : 3313, $3245(\mathrm{~b}, v(\mathrm{~N}-\mathrm{H})), 1731(\mathrm{~s}, v(\mathrm{C}=\mathrm{O})), 1588(\mathrm{~s}, v(\mathrm{C}=\mathrm{O})), 1541(\mathrm{~s}, v(\mathrm{C}-\mathrm{N})), 1253(\mathrm{~s}, v(\mathrm{C}-\mathrm{O}))$, 1206 (s, v(C-O)), 1145 (s, v(C-O)). UV-Vis (DMSO): $\varepsilon_{335}=1520 \mathrm{~L} / \mathrm{mol} \cdot \mathrm{cm} \mathrm{MS} \mathrm{(ESI/Positive)}$ MW: $\left(\mathrm{C}_{14} \mathrm{H}_{25} \mathrm{~N}_{3} \mathrm{O}_{6} \mathrm{Pd}\right)=435.7730, \mathrm{~m} / z$ found $($ calc $)=458.0515(458.0520)\left[\mathrm{M}+\mathrm{Na}^{+}\right]$. CHN $\left(\mathrm{C}_{14} \mathrm{H}_{23} \mathrm{~N}_{3} \mathrm{O}_{6} \mathrm{Pd}\right)$ found(calc)\%: C: 38.36(38.59), $\mathrm{H}: 5.25(5.32), \mathrm{N}: 9.64(9.64)$.

Route 2: $\alpha-\mathrm{D}\left(\mathrm{O}^{t} \mathrm{Bu}\right) \mathrm{AG}(\mathrm{OMe})(0.120 \mathrm{~g}, 0.362 \mathrm{mmol})$ dissolved in $10 \mathrm{~mL} \mathrm{H}_{2} \mathrm{O}$ was added to an aqueous solution of $\mathrm{K}_{2} \mathrm{PdCl}_{4}(0.146 \mathrm{~g}, 0.362 \mathrm{mmol})$ in $20 \mathrm{~mL} \mathrm{H}_{2} \mathrm{O}$. The pH was increased to 10 with $\mathrm{KOH}$ and stir for $0.5 \mathrm{~h}$. The water was removed, and the product was isolated by dissolving in acetonitrile and filtering. Presence of $\mathbf{8}$ was confirmed spectroscopically, but purification was unsuccessful.

\subsection{6. $\operatorname{Pd}\left\{\beta-\mathrm{Asp}\left(\mathrm{O}^{t} \mathrm{Bu}\right) \operatorname{AlaGly}(\mathrm{OMe})\right\}(\mathbf{1 0})$}

Ligand $2(0.331 \mathrm{~g}, 1.000 \mathrm{mmol})$ and Proton Sponge $(0.536 \mathrm{~g}, 2.500 \mathrm{mmol})$ were dissolved in THF $(20 \mathrm{~mL}) . \mathrm{Pd}(\mathrm{OAc})_{2}(0.224 \mathrm{~g}, 1.000 \mathrm{mmol})$ was added, and the reaction stirred under Ar for $5 \mathrm{~h}$. The solution was concentrated in vacuo and precipitated out with several additions of EtOAc and toluene. Product was recrystallized as a red-orange solid from acetonitrile and EtOAc $(0.287 \mathrm{~g}, 65.8 \%){ }^{1} \mathrm{H}-\mathrm{NMR}\left(400 \mathrm{MHz}, \mathrm{DMSO}-d_{6}\right) \delta 4.62(\mathrm{~m}, 1 \mathrm{H}$, 
$\left.\mathrm{NH}_{\text {Asp }}\right), 4.48\left(\mathrm{~m}, 1 \mathrm{H}, \mathrm{NH}_{\mathrm{Asp}}\right), 3.95\left(\mathrm{~m}, 1 \mathrm{H}, \alpha-\mathrm{H}_{\mathrm{Ala}}\right), 3.72-3.52\left(\mathrm{~m}, 2 \mathrm{H}, \alpha-\mathrm{H}_{\mathrm{Gly}}\right), 3.56(\mathrm{~s}, 3 \mathrm{H}$, $\left.-\mathrm{OCH}_{3 \mathrm{Gly}}\right), 3.18\left(\mathrm{~s}, 1 \mathrm{H}, \alpha-\mathrm{H}_{\text {Asp }}\right), 2.44-2.22\left(\mathrm{~m}, 2 \mathrm{H}, \beta-\mathrm{H}_{\mathrm{Asp}}\right), 1.44\left(\mathrm{~s}, 9 \mathrm{H},-\mathrm{O}\left(\mathrm{CH}_{3}\right)_{3} \mathrm{Asp}\right), 1.08$ $\left(\mathrm{d}, 3 \mathrm{H}, \beta-\mathrm{H}_{\mathrm{Ala}}\right) ;{ }^{13} \mathrm{C}$ NMR $(101 \mathrm{MHz}, \mathrm{DMSO}) \delta 172.88\left(\mathrm{C}=\mathrm{O}_{\mathrm{Asp}}\right), 171.14\left(\mathrm{C}=\mathrm{O}_{\mathrm{Ala}}\right), 170.16$ $\left(\gamma-\mathrm{C}=\mathrm{O}_{\mathrm{Asp}}\right), 99.49\left(\mathrm{C}=\mathrm{O}_{\mathrm{Gly}}\right), 82.32\left(\mathrm{OC}\left(\mathrm{CH}_{3}\right)_{3 \mathrm{Asp}}\right), 51.26\left(\mathrm{OCH}_{3 \mathrm{Gly}}\right), 54.70\left(\alpha-\mathrm{C}_{\mathrm{Asp}}\right), 59.14$ $\left(\alpha-\mathrm{C}_{\mathrm{Ala}}\right), 46.20\left(\alpha-\mathrm{C}_{\mathrm{Gly}}\right), 41.09\left(\beta-\mathrm{C}_{\mathrm{Asp}}\right), 28.13\left(\mathrm{OC}\left(\mathrm{CH}_{3}\right)_{3 \mathrm{Asp}}\right), 21.07\left(\beta-\mathrm{C}_{\mathrm{Ala}}\right) . \mathrm{IR}(\mathrm{KBr}) \mathrm{cm}^{-1}$ : 3313, $3245(\mathrm{~b}, v(\mathrm{~N}-\mathrm{H})), 1731(\mathrm{~s}, \mathrm{v}(\mathrm{C}=\mathrm{O})), 1588(\mathrm{~s}, \mathrm{v}(\mathrm{C}=\mathrm{O})), 1541(\mathrm{~s}, \mathrm{v}(\mathrm{C}-\mathrm{N})), 1253(\mathrm{~s}, \mathrm{v}(\mathrm{C}-\mathrm{O}))$, 1206 (s, v(C-O)), $1145(\mathrm{~s}, v(\mathrm{C}-\mathrm{O}))$. UV-Vis (DMSO): $\varepsilon_{333}=1260 \mathrm{~L} / \mathrm{mol} \cdot \mathrm{cm}$ MS (ESI $/$ Positive) MW: $\left(\mathrm{C}_{14} \mathrm{H}_{25} \mathrm{~N}_{3} \mathrm{O}_{6} \mathrm{Pd}\right)=435.7730, m / z$ found (calc) $=458.0515(458.0520)\left[\mathrm{M}+\mathrm{Na}^{+}\right]$. CHN $\left(\mathrm{C}_{14} \mathrm{H}_{23} \mathrm{~N}_{3} \mathrm{O}_{6} \mathrm{Pd}\right) \mathrm{C}: 38.28(38.59), \mathrm{H}: 5.24(5.32), \mathrm{N}: 9.69(9.64)$.

\subsection{7. $\mathrm{Pd}\{\operatorname{Trp} A l a G l y(\mathrm{OMe})\}(\mathbf{1 1})$}

Ligand $3(0.143 \mathrm{~g}, 0.413 \mathrm{mmol})$ and Proton Sponge $(0.221 \mathrm{~g}, 1.032 \mathrm{mmol})$ were dissolved in THF $(20 \mathrm{~mL}) . \mathrm{Pd}(\mathrm{OAc})_{2}(0.093 \mathrm{~g}, 0.413 \mathrm{mmol})$ was added, and the reaction stirred under Ar for $5 \mathrm{~h}$. The solution was concentrated in vacuo and precipitated out with $\mathrm{Et}_{2} \mathrm{O}$. The orange solid was collected and washed with portions of EtOAc and $\mathrm{Et}_{2} \mathrm{O}$. Hot $\mathrm{CH}_{3} \mathrm{CN}$ was used to redissolve the product, product was filtered and concentrated in vacuo. $(0.169 \mathrm{~g}, 90.0 \%) ;{ }^{1} \mathrm{H}-\mathrm{NMR}\left(400 \mathrm{MHz}, \mathrm{DMSO}-d_{6}\right) \delta 10.90\left(\mathrm{~d}, 1 \mathrm{H}, \mathrm{NH}_{\text {indole }}\right), 7.55(\mathrm{~d}$, $\left.1 \mathrm{H}, \mathrm{H}_{\text {indole-C } \mathrm{C}}\right), 7.37\left(\mathrm{~d}, 2 \mathrm{H}, \mathrm{H}_{\text {indole- } \mathrm{C} 4}\right), 7.27\left(\mathrm{~d}, 2 \mathrm{H}, \mathrm{H}_{\text {indole- } \mathrm{C} 2}\right), 7.09\left(\mathrm{ddd}, 1 \mathrm{H}, \mathrm{H}_{\text {indole-C }}\right)$, 6.99 (ddd, $\left.1 \mathrm{H}, \mathrm{H}_{\text {indole- } \mathrm{C} 6}\right), 4.96\left(\mathrm{t}, 1 \mathrm{H}, \mathrm{NH}_{\text {Trp }}\right), 4.24\left(\mathrm{t}, 1 \mathrm{H}, \mathrm{NH}_{\text {Trp }}\right), 3.96\left(\mathrm{~d}, 1 \mathrm{H}, \alpha-\mathrm{H}_{\mathrm{Gly}}\right)$, $3.83\left(\mathrm{~d}, 1 \mathrm{H}, \alpha-\mathrm{H}_{\mathrm{Gly}}\right), 3.82-3.75\left(\mathrm{~m}, 2 \mathrm{H}, \alpha-\mathrm{H}_{\mathrm{Ala}}\right), 3.55\left(\mathrm{~s}, 4 \mathrm{H}, \mathrm{ROCH}_{3 \mathrm{Gly}}\right), 3.40(\mathrm{dt}, 2 \mathrm{H}$, $\left.\alpha-\mathrm{H}_{\text {Trp }}\right), 3.28\left(\mathrm{dd}, 1 \mathrm{H}, \beta-\mathrm{H}_{\text {Trp }}\right), 2.87\left(\mathrm{dd}, 2 \mathrm{H}, \beta-\mathrm{H}_{\text {Trp }}\right), 1.24\left(\mathrm{~d}, 3 \mathrm{H}, \beta-\mathrm{H}_{\mathrm{Ala}}\right) ;{ }^{13} \mathrm{C}-\mathrm{NMR}$ $(101 \mathrm{MHz}, \mathrm{DMSO}) \delta 178.24\left(\mathrm{C}=\mathrm{O}_{\mathrm{Tr} p}\right), 172.93\left(\mathrm{C}=\mathrm{O}_{\mathrm{Ala}}\right), 136.37\left(\mathrm{C}_{\text {indole }}\right), 127.11\left(\mathrm{C} 8_{\text {indole }}\right)$, $123.99\left(\mathrm{C} 2_{\text {indole }}\right), 121.10\left(\mathrm{C} 5_{\text {indole }}\right), 118.44\left(\mathrm{C}_{\text {indole }}\right), 118.24\left(\mathrm{C}_{\text {indole }}\right), 111.41\left(\mathrm{C} 4_{\text {indole }}\right), 109.47$ $\left(\mathrm{C}_{\text {indole }}\right), 67.00,59.58\left(\alpha-\mathrm{C}_{\mathrm{Gly}}\right), 56.50\left(\mathrm{OCH}_{3 \mathrm{Gly}}\right), 50.93\left(\alpha-\mathrm{C}_{\mathrm{Ala}}\right), 46.86\left(\alpha-\mathrm{C}_{\mathrm{Gly}}\right), 29.93\left(\beta-\mathrm{C}_{\mathrm{Trp}}\right)$, 19.92( $\left.\beta-\mathrm{C}_{\mathrm{Ala}}\right)$. IR (KBr) $\mathrm{cm}^{-1}: 3370,3286,3235(\mathrm{~b}, v(\mathrm{~N}-\mathrm{H})), 1741(\mathrm{~s}, v(\mathrm{C}=\mathrm{O})), 1569(\mathrm{sh})(\mathrm{s}$, $v(\mathrm{C}=\mathrm{O})), 1543(v(\mathrm{C}-\mathrm{N})), 1333,1070,1010(v(\mathrm{C}-\mathrm{N})), 1105(\mathrm{sh}), 1025,981(v(\mathrm{C}-\mathrm{N})), 1207(v(\mathrm{C}-\mathrm{O}))$, $1178(\mathrm{~s}, v(\mathrm{C}-\mathrm{O}))$. UV-Vis (DMSO): $\varepsilon_{317}=3239, \varepsilon_{344}=2188 \mathrm{~L} / \mathrm{mol} \cdot \mathrm{cm} \mathrm{MS} \mathrm{(ESI} /$ Positive) MW: $\left(\mathrm{C}_{17} \mathrm{H}_{20} \mathrm{~N}_{4} \mathrm{O}_{4} \mathrm{Pd}\right)=450.7910, m / z$ found $($ calc $)=437.0417(437.0419)\left[\mathrm{M}+\mathrm{Na}^{+}\right]$. CHN $\left(\mathrm{C}_{17} \mathrm{H}_{20} \mathrm{~N}_{4} \mathrm{O}_{4} \mathrm{Pd}\right)$ found(calc)\%: C: 44.51(43.55), H: 4.73(4.73), N: 11.47(11.95).

\subsection{Reaction Studies \\ 4.2.1. Sulfur Reagents}

Samples of 9-11 were prepared aerobically by adding cyclohexene sulfide $(0.3833 \mathrm{mmol})$ to DMSO- $d_{6}(0.6 \mathrm{~mL})$ in screw-cap NMR tub. Initial ${ }^{1} \mathrm{H}-\mathrm{NMR}$ spectrum were recorded at ambient temperature and pressure to obtain a blank spectrum. Complexes 9-11 $(0.0115 \mathrm{mmol})$ were added to NMR tube and ${ }^{1} \mathrm{H}-\mathrm{NMR}$ spectrum for recorded instantly. The progress of the reaction was monitored over the course of hours or days to determine conversion of thiirane to alkene. Maintaining conditions but omitting the catalyst showed no identifiable alkene formation over commensurate time periods as the catalytic runs.

\subsubsection{Ethylene and Acids}

NMR tube was charged with complex 9 or $10(10.1 \mathrm{mg}, 0.023 \mathrm{mmol})$ and dissolved in $650 \mu \mathrm{L}$ of DMSO-d6, the NMR recorded, then ethylene was bubbled in for $1 \mathrm{~min}$, and the NMR recorded again (Figure S10). TFA $(\sim 20 \mu \mathrm{L}, 0.128 \mathrm{mmol} ; 30 \mu \mathrm{L}, 0.192 \mathrm{mmol}$; $\sim 40 \mu \mathrm{L}(0.256 \mathrm{mmol})$ or TFMS $(\sim 40 \mu \mathrm{L}, 0.443 \mathrm{mmol})$ was added to the NMR tube and the spectrum recorded again. Complex $8(9.7 \mathrm{mg}, 0.022 \mathrm{mmol})$ was dissolved in $650 \mu \mathrm{L}$ of DMSO-d6, then TFA $(\sim 20 \mu \mathrm{L}, 0.128 \mathrm{mmol})$ was added and the spectrum recorded; ethylene was bubbled in and the NMR recorded again.

\subsection{Quantum Chemical Calculations}

Calculations were performed with version 4.2 .1 of the ORCA program [61,62]. The density functional theory based protocol consisted of the PBE0-D3BJ functional [63-65] (including the D3 dispersion correction by Grimme and coworkers $[66,67]$ ) and the triplezeta basis set def2-TZVP [68]. The RIJCOSX [69,70] approximation was used to calcu- 
late Coulomb and Exchange integrals, using the def2/J auxiliary basis set by Weigend et al. [71] and the GridX5 (ORCA keyword) grid was used. Tighter grids for the exchangecorrelation terms were also used (Grid5, FinalGrid6 keywords in ORCA). The CPCM solvation model [72-74] using a Gaussian point charge scheme and a scaled vdW surface was used to incorporate solvation effects. Vibrational frequencies were calculated analytically, as implemented in ORCA $[75,76]$. The ${ }^{13} \mathrm{C}-\mathrm{NMR}$ shieldings were calculated using the same level of theory, except the pcSseg-2 basis sets [77] were utilized on carbon and hydrogen atoms. The calculated shieldings were converted into chemical shifts by calculating the shielding difference with respect to tetramethylsilane at the same level of theory. Chemical shifts were shifted by $-15 \mathrm{ppm}$ due to a systematic overestimation.

Supplementary Materials: The following are available online. Figures S1-S6: The ${ }^{1} \mathrm{H}-\mathrm{NMR},{ }^{13} \mathrm{C}-$ NMR and MS for 4, 7, 8-11, Tables S1 and S2: The ${ }^{1} \mathrm{H}$ and ${ }^{13} \mathrm{C}-\mathrm{NMR}$ data for 1-3, Figure S7: stacked IR spectra for 1, 4, 8, and $9^{\prime}$ Figure S8: the ${ }^{1} \mathrm{H}-\mathrm{NMR}$ spectra for 10 in DMSO- $d_{6}$ : sulfur transfer reactions, Figure S9: example of reaction progress for SAT by 10 in DMSO- $d_{6}$, Figure S10: stacked ${ }^{1} \mathrm{H}-\mathrm{NMR}$ spectra of reactions of 9 (1) with ethylene and acids. DFT generated cartesian coordinates for complexes 4, 8-11 in Ångstrom.

Author Contributions: Conceptualization, S.G.S. and L.J.M.; methodology, S.G.S. and L.J.M.; software, R.B.; validation, S.G.S., R.B. and L.J.M.; formal analysis, L.J.M., S.G.S., D.R. and R.B.; investigation, L.J.M. and D.R.; resources, S.G.S. and R.B.; data curation, S.G.S., L.J.M., D.R. and R.B.; writing—original draft preparation, L.J.M.; writing—review and editing, S.G.S., L.J.M. and R.B.; visualization, L.J.M. and R.B.; supervision, S.G.S.; project administration, S.G.S.; funding acquisition, S.G.S. All authors have read and agreed to the published version of the manuscript.

Funding: Financial support by The Icelandic Centre of Research (Rannis) grant nr 152323 and by The University of Iceland Research Assistantship Fund are gratefully acknowledged.

Institutional Review Board Statement: Not applicable.

Informed Consent Statement: Not applicable.

Data Availability Statement: Not applicable.

Acknowledgments: Sigridur Jonsdottir is thanked for assistance with high temperature NMR experiments and for mass spectral data.

Conflicts of Interest: The authors declare no conflict of interest.

Sample Availability: Samples of the compounds are not available from the authors.

\section{References}

1. Kitteringham, E.; McKeon, A.M.; O’Dowd, P.; Devocelle, M.; Murphy, B.M.; Griffith, D.M. Synthesis and Characterisation of a Novel Mono Functionalisable Pt(IV) Oxaliplatin-Type Complex and Its Peptide Conjugate. Inorg. Chim. Acta 2020, 505, 119492. [CrossRef]

2. Metzler-Nolte, N.; Guo, Z. Themed Issue on “Metallodrugs: Activation, Targeting, and Delivery". Dalton Trans. 2016, 45, 12965. [CrossRef]

3. Bradford, S.S.; Cowan, J.A. From Traditional Drug Design to Catalytic Metallodrugs: A Brief History of the Use of Metals in Medicine. Metallodrugs 2014, 1, 10-23. [CrossRef]

4. Soldevila-Barreda, J.J.; Sadler, P.J. Approaches to the Design of Catalytic Metallodrugs. Curr. Opin. Chem. Biol. 2015, 25, 172-183. [CrossRef]

5. Mjos, K.D.; Orvig, C. Metallodrugs in Medicinal Inorganic Chemistry. Chem. Rev. 2014, 114, 4540-4563. [CrossRef]

6. Ward, T.R. ACS Central Science Virtual Issue on Bioinspired Catalysis. ACS Cent. Sci. 2019, 5, 1732-1735. [CrossRef]

7. Sigel, H.; Martin, R.B. Coordinating Properties of the Amide Bond. Stability and Structure of Metal Ion Complexes of Peptides and Related Ligands. Chem. Rev. 1982, 82, 385-426. [CrossRef]

8. Sóvágó, I.; Ősz, K. Metal Ion Selectivity of Oligopeptides. Dalton Trans. 2006, 32, 3841-3854. [CrossRef]

9. Murphy, J.M.; Powell, B.A.; Brumaghim, J.L. Stability Constants of Bio-Relevant, Redox-Active Metals with Amino Acids: The Challenges of Weakly Binding Ligands. Coord. Chem. Rev. 2020, 412, 213253. [CrossRef]

10. Kozłowski, H.; Bal, W.; Dyba, M.; Kowalik-Jankowska, T. Specific Structure-Stability Relations in Metallopeptides. Coord. Chem. Rev. 1999, 184, 319-346. [CrossRef]

11. El-Sherif, A.A. Coordination chemistry of palladium (II) ternary complexes with relevant biomolecules. Stoichiometry and Research. In The Importance of Quantity in Biomedicine; IntechOpen: London, UK, 2012; pp. 80-120. 
12. Jószai, V.; Nagy, Z.; Ősz, K.; Sanna, D.; Di Natale, G.; La Mendola, D.; Pappalardo, G.; Rizzarelli, E.; Sóvágó, I. Transition Metal Complexes of Terminally Protected Peptides Containing Histidyl Residues. J. Inorg. Biochem. 2006, 100, 1399-1409. [CrossRef] [PubMed]

13. Livingstone, S.E.; Nolan, J.D. Metal Chelates of Biologically Important Compounds. I. Complexes of DL-Ethionine and S-MethylL-Cysteine. Inorg. Chem. 1968, 7, 1447-1451. [CrossRef]

14. Chandrasekharan, M.; Udupa, M.R.; Aravamudan, G. Cysteine Complexes of Palladium(II) and Platinum(II). Inorg. Chim. Acta 1973, 7, 88-90. [CrossRef]

15. Pettit, L.D.; Bezer, M. Complex Formation between Palladium(II) and Amino Acids, Peptides and Related Ligands. Coord. Chem. Rev. 1985, 61, 97-114. [CrossRef]

16. McAuliffe, C.A. The Infrared Spectra of Palladium(II) and Platinum(II) Complexes of ( \pm )-Methionine. J. Chem. Soc. A 1967, 0 , 641-642. [CrossRef]

17. Ágoston, C.G.; Jankowska, T.K.; Sóvágó, I. Potentiometric and NMR Studies on Palladium(II) Complexes of Oligoglycines and Related Ligands with Non-Co-Ordinating Side Chains. J. Chem. Soc. Dalton Trans. 1999, 18, 3295-3302. [CrossRef]

18. Wilson, E.W.; Martin, R.B. Circular Dichroism of Palladium(II) Complexes of Amino Acids and Peptides. Inorg. Chem. 1970, 9 , 528-532. [CrossRef]

19. Maiti, B.K.; Govil, N.; Kundu, T.; Moura, J.J.G. Designed Metal-ATCUN Derivatives: Redox- and Non-Redox-Based Applications Relevant for Chemistry, Biology, and Medicine. iScience 2020, 23, 101792. [CrossRef]

20. Perinelli, M.; Guerrini, R.; Albanese, V.; Marchetti, N.; Bellotti, D.; Gentili, S.; Tegoni, M.; Remelli, M. Cu(II) Coordination to His-Containing Linear Peptides and Related Branched Ones: Equalities and Diversities. J. Inorg. Biochem. 2020, $205,110980$. [CrossRef]

21. Gonzalez, P.; Bossak, K.; Stefaniak, E.; Hureau, C.; Raibaut, L.; Bal, W.; Faller, P. N-Terminal Cu-Binding Motifs (Xxx-Zzz-His, Xxx-His) and Their Derivatives: Chemistry, Biology and Medicinal Applications. Chem. Eur. J. 2018, 24, 8029-8041. [CrossRef]

22. Peana, M.; Gumienna-Kontecka, E.; Piras, F.; Ostrowska, M.; Piasta, K.; Krzywoszynska, K.; Medici, S.; Zoroddu, M.A. Exploring the Specificity of Rationally Designed Peptides Reconstituted from the Cell-Free Extract of Deinococcus radiodurans toward Mn(II) and $\mathrm{Cu}(\mathrm{II})$. Inorg. Chem. 2020, 59, 4661-4684. [CrossRef]

23. Vicatos, G.M.; Jackson, G.E.; Hammouda, A.N.; Bonomo, R.P.; Valora, G. Potentiometric and Spectroscopic Studies of the Complex Formation between Copper(II) and Gly-Leu-Phe or Sar-Leu-Phe Tripeptides. Polyhedron 2019, 170, 553-563. [CrossRef]

24. Gavrish, S.P.; Lampeka, Y.D.; Babak, M.V.; Arion, V.B. Palladium Complexes of $N, N^{\prime}$-Bis(2-Aminoethyl)Oxamide (H2L): Structural (PdIIL, PdII2L2, and PdIVLC12), Electrochemical, Dynamic 1H NMR, and Cytotoxicity Studies. Inorg. Chem. 2018, 57, 1288-1297. [CrossRef]

25. Gonzalez, P.; Vileno, B.; Bossak, K.; El Khoury, Y.; Hellwig, P.; Bal, W.; Hureau, C.; Faller, P. Cu(II) Binding to the Peptide Ala-His-His, a Chimera of the Canonical Cu(II)-Binding Motifs Xxx-His and Xxx-Zzz-His. Inorg. Chem. 2017, 56, 14870-14879. [CrossRef] [PubMed]

26. Park, G.Y.; Lee, J.Y.; Himes, R.A.; Thomas, G.S.; Blackburn, N.J.; Karlin, K.D. Copper-Peptide Complex Structure and Reactivity When Found in Conserved His- $\mathrm{X}_{\mathrm{aa}}-$ His Sequences. J. Am. Chem. Soc. 2014, 136, 12532-12535. [CrossRef] [PubMed]

27. Sóvágó, I.; Kállay, C.; Várnagy, K. Peptides as Complexing Agents: Factors Influencing the Structure and Thermodynamic Stability of Peptide Complexes. Coord. Chem. Rev. 2012, 256, 2225-2233. [CrossRef]

28. Griffith, D.M.; Bíró, L.; Platts, J.A.; Müller-Bunz, H.; Farkas, E.; Buglyó, P. Synthesis and Solution Behaviour of Stable Mono-, Diand Trinuclear Pd(II) Complexes of 2,5-Pyridinedihydroxamic Acid: X-Ray Crystal Structure of a Novel Pd(II) Hydroxamato Complex. Inorg. Chim. Acta 2012, 380, 291-300. [CrossRef]

29. Gábor Ágoston, C.; Miskolczy, Z.; Nagy, Z.; Sóvágó, I. The Effect of Ring Size of Fused Chelates on the Stability Constants and Spectroscopic Properties of Nickel(II) and Palladium(II) Complexes of Peptides. Polyhedron 2003, 22, 2607-2615. [CrossRef]

30. Hay, R.W.; Pujari, M.P. The Palladium(II) Promoted Hydrolysis of Methyl, Ethyl and Isopropyl Glycylglycylglycinate. Inorg. Chim. Acta 1986, 123, 47-51. [CrossRef]

31. Monger, L.J.; Runarsdottir, G.R.; Suman, S.G. Directed Coordination Study of $\left[\mathrm{Pd}(\mathrm{En})\left(\mathrm{H}_{2} \mathrm{O}\right)_{2}\right]^{2+}$ with Hetero-Tripeptides Containing C-Terminus Methyl Esters Employing NMR Spectroscopy. J. Biol. Inorg. Chem. 2020, 25, 811-825. [CrossRef]

32. Chen, S.; Vasquez, L.; Noll, B.C.; Rakowski DuBois, M. Synthesis and Characterization of Mononuclear Indoline Complexes. Studies of $\sigma$ and $\pi$ Bonding Modes. Organometallics 1997, 16, 1757-1764. [CrossRef]

33. Sundberg, R.J. Electrophilic Substitution Reactions of Indoles. In Heterocyclic Scaffolds II; Gribble, G.W., Ed.; Topics in Heterocyclic Chemistry; Springer: Berlin/Heidelberg, Germany, 2010; Volume 26, pp. 47-115. ISBN 978-3-642-15732-5.

34. Singh, M.P.; Saleem, F.; Pal, R.S.; Singh, A.K. Palladacycles Having Normal and Spiro Chelate Rings Designed from Bi- and Tridentate Ligands with an Indole Core: Structure, Synthesis and Applications as Catalysts. New J. Chem. 2017, 41, 11342-11352. [CrossRef]

35. Kaminskaia, N.V.; Ullmann, G.M.; Fulton, D.B.; Kostić, N.M. Spectroscopic, Kinetic, and Mechanistic Study of a New Mode of Coordination of Indole Derivatives to Platinum(II) and Palladium(II) Ions in Complexes. Inorg. Chem. 2000, 39, 5004-5013. [CrossRef] [PubMed]

36. Jack Mccormick, B.; Jaynes, E.N.; Kaplan, R.I.; Clark, H.C.; Ruddick, J.D. Dichloro(ethylenediamine)palladium(II). In Inorganic Syntheses; Cotton, F.A., Ed.; John Wiley \& Sons, Inc.: Hoboken, NJ, USA, 2007; pp. 216-218. ISBN 978-0-470-13244-9. 
37. Walton, R.A. The Infra-Red Spectra of Complexes of Palladium (II) and Platinum (II) Halides with Methyl Phenyl Cyanides. Spectrochim. Acta 1965, 21, 1795-1801. [CrossRef]

38. Rochon, F.D.; Melanson, R.; Howard-Lock, H.E.; Lock, C.J.L.; Turner, G. The Vibrational Spectra, Crystal and Molecular Structure of Bis(Acetonitrile)Dichloroplatinum(II). Can. J. Chem. 1984, 62, 860-869. [CrossRef]

39. Schreiner, B.; Robl, C.; Wagner-Schuh, B.; Beck, W. Metal Complexes of Biologically Important Ligands, CLXXIV [1]. Palladium(II) and Platinum(II) Complexes with Schiff Bases from 2-(Diphenylphosphino)Benzaldehyde and $\alpha$-Amino Acid Esters. Z. Nat. B 2010, 65, 503-510. [CrossRef]

40. Nakamoto, K. Infrared and Raman Spectra of Inorganic and Coordination Compounds, 6th ed.; Wiley: Hoboken, NJ, USA, 2009; ISBN 978-0-471-74339-2.

41. Zhu, L.; Kostic, N.M. Toward Artificial Metallopeptidases: Mechanisms by Which Platinum(II) and Palladium(II) Complexes Promote Selective, Fast Hydrolysis of Unactivated Amide Bonds in Peptides. Inorg. Chem. 1992, 31, 3994-4001. [CrossRef]

42. Carvalho, M.A.; Souza, B.C.; Paiva, R.E.F.; Bergamini, F.R.G.; Gomes, A.F.; Gozzo, F.C.; Lustri, W.R.; Formiga, A.L.B.; Rigatto, G.; Corbi, P.P. Synthesis, Spectroscopic Characterization, DFT Studies, and Initial Antibacterial Assays in Vitro of a New Palladium(II) Complex with Tryptophan. J. Coord. Chem. 2012, 65, 1700-1711. [CrossRef]

43. Bontchev, P.R.; Boneva, M.; Arnaudov, M.; Nefedov, V.I. Palladium(II) Complexes of Hydrazides of Aspartic and Glutamic Acids. Inorg. Chim. Acta 1984, 81, 75-81. [CrossRef]

44. Schreiner, B.; Beck, W. Coordination of the Ester Group-Hydrido-Rhodium(III) and Iridium(III) Complexes of Orthometallated Diphenylmethylene Glycine Esters [1]. Z. Anorg. Allg. Chem. 2010, 636, 499-505. [CrossRef]

45. Liu, J.; Deng, Y.; Lin, C.; Lei, A. "Push Effect" of Sulfur Coordination: Promoting the Breaking of C(Sp2)-I Bond by Pincer Thioimido-Pd(II) Complexes. Chem. Sci. 2012, 3, 1211. [CrossRef]

46. Silvano, S.; Carrozza, C.F.; de Angelis, A.R.; Tritto, I.; Boggioni, L.; Losio, S. Synthesis of Sulfur-Rich Polymers: Copolymerization of Cyclohexene Sulfide and Carbon Disulfide Using Chromium Complexes. Macromolecules 2020, 53, 8837-8846. [CrossRef]

47. Hagen, J. Industrial Catalysis: A Practical Approach, 3rd ed.; Wiley-VCH: Weinheim, Germany, 2015; ISBN 978-3-527-33165-9.

48. Wang, F.; Chen, C. A Continuing Legend: The Brookhart-Type $\alpha$-Diimine Nickel and Palladium Catalysts. Polym. Chem. 2019, 10, 2354-2369. [CrossRef]

49. Shi, P.-Y.; Liu, Y.-H.; Peng, S.-M.; Liu, S.-T. Palladium(II) Complexes Containing P N NO Donors. Ligand Effect of Tridentate versus Bidentate Coordination on the Oligomerization of Ethylene. Organometallics 2002, 21, 3203-3207. [CrossRef]

50. Howells, R.D.; Mc Cown, J.D. Trifluoromethanesulfonic Acid and Derivatives. Chem. Rev. 1977, 77, 69-92. [CrossRef]

51. Gramstad, T.; Haszeldine, R.N. 806. Perfluoroalkyl Derivatives of Sulphur. Part VII. Alkyl Trifluoromethanesulphonates as Alkylating Agents, Trifluoromethanesulphonic Anhydride as a Promoter for Esterification, and Some Reactions of Trifluoromethanesulphonic. Acid. J. Chem. Soc. 1957, 4069. [CrossRef]

52. Núñez Magro, A.A.; Robb, L.-M.; Pogorzelec, P.J.; Slawin, A.M.Z.; Eastham, G.R.; Cole-Hamilton, D.J. Highly Selective Formation of Unsaturated Esters or Cascade Reactions to $\alpha, \omega$-Diesters by the Methoxycarbonylation of Alkynes Catalysed by Palladium Complexes of 1,2-Bis(Ditertbutylphosphinomethyl)Benzene. Chem. Sci. 2010, 1, 723. [CrossRef]

53. Suleiman, R.; Tijani, J.; El Ali, B. Palladium(II)-Catalyzed Catalytic Aminocarbonylation and Alkoxycarbonylation of Terminal Alkynes: Regioselectivity Controlled by the Nucleophiles. Appl. Organometal. Chem. 2009, 24, 38-46. [CrossRef]

54. Katafuchi, Y.; Fujihara, T.; Iwai, T.; Terao, J.; Tsuji, Y. Palladium-Catalyzed Hydroesterification of Alkynes Employing Aryl Formates without the Use of External Carbon Monoxide. Adv. Synth. Catal. 2011, 353, 475-482. [CrossRef]

55. Dong, K.; Sang, R.; Liu, J.; Razzaq, R.; Franke, R.; Jackstell, R.; Beller, M. Palladium-Catalyzed Carbonylation of sec- and tert-Alcohols. Angew. Chem. Int. Ed. 2017, 56, 6203-6207. [CrossRef]

56. Sang, R.; Schneider, C.; Razzaq, R.; Neumann, H.; Jackstell, R.; Beller, M. Palladium-Catalyzed Carbonylations of Highly Substituted Olefins Using CO-Surrogates. Org. Chem. Front. 2020, 7, 3681-3685. [CrossRef]

57. Razinkov, D.; Ingvarsdottir, H.I.; Kvaran, Á.; Jonsdottir, S.; Suman, S.G. Coordination Properties of Non-Rigid Phosphinoyldithioformate Complexes of the $\left[\mathrm{Mo}_{2} \mathrm{O}_{2}(\mu-\mathrm{S})_{2}\right]^{2+}$ Cation in Catalytic Sulfur Transfer Reactions with Thiiranes. Catalysts 2021, 11, 593. [CrossRef]

58. Takacs, J.; Jiang, X. The Wacker Reaction and Related Alkene Oxidation Reactions. COC 2003, 7, 369-396. [CrossRef]

59. Armarego, W.L.F.; Chai, C.L.L. Purification of Laboratory Chemicals, 5th ed.; Butterworth-Heinemann: Amsterdam, The Netherlands; Boston, MA, USA, 2003; ISBN 978-0-7506-7571-0.

60. Carretero, J.C.; Arrayás, R.G. Dichloro Bis(acetonitrile) Palladium. In Encyclopedia of Reagents for Organic Synthesis; John Wiley \& Sons, Ltd.: Chichester, UK, 2008; p. rn00908. ISBN 978-0-471-93623-7.

61. Neese, F. The ORCA Program System. WIREs Comput. Mol. Sci. 2012, 2, 73-78. [CrossRef]

62. Neese, F. Software Update: The ORCA Program System, Version 4.0. WIREs Comput. Mol. Sci. 2018, 8, e1327. [CrossRef]

63. Shi, G.; Dang, Y.; Pan, T.; Liu, X.; Liu, H.; Li, S.; Zhang, L.; Zhao, H.; Li, S.; Han, J.; et al. Unexpectedly Enhanced Solubility of Aromatic Amino Acids and Peptides in an Aqueous Solution of Divalent Transition-Metal Cations. Phys. Rev. Lett. 2016, 117, 238102. [CrossRef]

64. Adamo, C.; Barone, V. Toward Reliable Density Functional Methods without Adjustable Parameters: The PBE0 Model. J. Chem. Phys. 1999, 110, 6158-6170. [CrossRef]

65. Perdew, J.P.; Ernzerhof, M.; Burke, K. Rationale for Mixing Exact Exchange with Density Functional Approximations. J. Chem. Phys. 1996, 105, 9982-9985. [CrossRef] 
66. Grimme, S.; Antony, J.; Ehrlich, S.; Krieg, H. A Consistent and Accurate Ab Initio Parametrization of Density Functional Dispersion Correction (DFT-D) for the 94 Elements H-Pu. J. Chem. Phys. 2010, 132, 154104. [CrossRef] [PubMed]

67. Grimme, S.; Ehrlich, S.; Goerigk, L. Effect of the Damping Function in Dispersion Corrected Density Functional Theory. J. Comput. Chem. 2011, 32, 1456-1465. [CrossRef] [PubMed]

68. Weigend, F.; Ahlrichs, R. Balanced Basis Sets of Split Valence, Triple Zeta Valence and Quadruple Zeta Valence Quality for H to Rn: Design and Assessment of Accuracy. Phys. Chem. Chem. Phys. 2005, 7, 3297. [CrossRef]

69. Neese, F.; Wennmohs, F.; Hansen, A.; Becker, U. Efficient, Approximate and Parallel Hartree-Fock and Hybrid DFT Calculations. A 'Chain-of-Spheres' Algorithm for the Hartree-Fock Exchange. Chem. Phys. 2009, 356, 98-109. [CrossRef]

70. Izsák, R.; Neese, F. An Overlap Fitted Chain of Spheres Exchange Method. J. Chem. Phys. 2011, 135, 144105. [CrossRef]

71. Weigend, F. Accurate Coulomb-Fitting Basis Sets for H to Rn. Phys. Chem. Chem. Phys. 2006, 8, 1057. [CrossRef]

72. Barone, V.; Cossi, M. Quantum Calculation of Molecular Energies and Energy Gradients in Solution by a Conductor Solvent Model. J. Phys. Chem. A 1998, 102, 1995-2001. [CrossRef]

73. York, D.M.; Karplus, M. A Smooth Solvation Potential Based on the Conductor-Like Screening Model. J. Phys. Chem. A 1999, 103, 11060-11079. [CrossRef]

74. Garcia-Ratés, M.; Neese, F. Effect of the Solute Cavity on the Solvation Energy and Its Derivatives within the Framework of the Gaussian Charge Scheme. J. Comput. Chem. 2020, 41, 922-939. [CrossRef]

75. Garcia-Ratés, M.; Neese, F. Efficient Implementation of the Analytical Second Derivatives of Hartree-Fock and Hybrid DFT Energies within the Framework of the Conductor-like Polarizable Continuum Model. J. Comput. Chem. 2019, 40, 1816-1828. [CrossRef] [PubMed]

76. Bykov, D.; Petrenko, T.; Izsák, R.; Kossmann, S.; Becker, U.; Valeev, E.; Neese, F. Efficient Implementation of the Analytic Second Derivatives of Hartree-Fock and Hybrid DFT Energies: A Detailed Analysis of Different Approximations. Mol. Phys. 2015, 113, 1961-1977. [CrossRef]

77. Jensen, F. Segmented Contracted Basis Sets Optimized for Nuclear Magnetic Shielding. J. Chem. Theory Comput. 2015, 11, 132-138. [CrossRef] [PubMed] 